41Dr. KHoloud Hossam - Dr. Nahed Helmy - Applying Islamic Rational Consumption

\title{
Applying Islamic Rational Consumption Perspective in Egypt
}

Dr. KHoloud Hossam

Assistant Professor of Economics

Faculty of Commerce

Department of Economics

;AL AZHAR UNIVERSITY
Dr. Nahed Helmy

Assistant Professor of Statistics

Faculty of Commerce

Department of Statistics

ALAZHAR UNIVERSITY

\section{Abstract}

This study investigated the impact of applying Islamic rationality on consumption in Egypt by using economic methods. We covered the period starting from year 2000 due to the changing in consumer taste as an impact of overwhelming globalization and, "place limitations: the study is concerned with Egypt, designing an Islamic consumption framework that may be applicable to Egypt and using the suggested framework to develop Islamic theory of consumer behavior, which will add the concept of "Rushd" (as - opposed to the concept of rationality in secular economics) in adjusting the consumption in Egypt. Finally, we found that the most important conclusion is that conventional economics should include normative and religious instrumient to attain the goal on consumer satisfaction. To achieve this goal, it is concerned with applying three methods of linear regression (ordinary least squares, least trimmed square and $\mathrm{M}$ - estimation) on the data of consumption and expenditure at 2015 in both urban and rural sectors to study the effect of some independent variables on the total expenditure (the dependent variable). A comparison between the three methods is made using the standard error and $R$ squared obtained. The relation between the dependent variable and independent variables is represented by the path analysis using the Amos program. Two of robust skewness and kurtosis measures are used to determine the shape of the distribution of the total annual income in both urban and rural sectors before and after removing the outliers in income data. It is suggested 
to calculate the Zakah by dividing the individuals into two groups (poor and nonpoor) according to the median of the income.

Key words: Ordinary least squares, Least trimmed square, M- Estimation square, Scale robust measure, Zakah, skewness robust measure, kurtosis robust measure, Path analysis, Expenditure groups.

\section{Introduction}

"Achievement of consumer's satisfaction" is the ultimate goal of economic theories either in Conventional economics or in Islamic Economics. Whereby, fulfilling consumer's satisfaction is through maximizing his utility which necessities "Rational behavior of the Consumer" in both economic systems. Thus, "Rationality" can be seen as the core of achieving consumer's satisfaction.According to "Oxford Dictionary", "Rationality" is defined as: "means based on or in accordance with reason or logic, able to think sensibly or logically and having the capacity to reason". And according to Islam "Rationality" is achieving the end through moderation in consumption (Wasatiyyah). Turning to conventional and Islamic economic systems, although in both cases a "Rational Consumer" is: "the one who is neither a miser nor a spendthrift", but still there are major differences in both systems vision of "Rationality". On one hand, Conventional Perspective views "Rationality" as maximizing only own self-interest without limits, earning at anyway, whereas morals, religious, social values are absent, moreover; no treatment is offered for immoral activities when practiced. Thus, "Conventior $=1$ Rational Consumer": refers to "An individual who spends his income in such a way as to achieve maximum satisfaction- to gain material benefits- even through a portion of this may te allocated for the consumption of alcoholic beverages". On the other hand, Isiamic Perspective views. "Rationality" as recognizing self-interest but in accordance 
with Shari'ah principles by ensuring religious, cultural, historical. and social values and also ensuring the achievement of the social welfare of the whole society through earning at honest means which aims at creating a balanced society. Thus, "Islamic Rational Consumer": is the one who seeks consuming the resources whom ALLAH is the owner- to achieve material and spiritual needs through spending on Halal (what is permissible in Shari'ah) and moderating spending. In the Quran ALLAH says:; "those who, when they spend, are not extravagant and not niggardly but hold a just.(balance) between those (extremes)". Thus, from the above mentioned, it can be concluded that the framework of the Islamic perspective of "Rational Consumer" is more comprehensive than the Conventional one.Therefore, the paper aims to apply Islamic Rational Consumption perspective in Egypt.

\section{Literature Review}

Heba (1990) aimed at presenting a theoretical framework for -some consumption theories, and then analyzing consumption functions applied in: Egypt, India, and Urban of South America. It resulted that on the national level, that the marginal propensity to consume in Egypt for private consumption is high; In addition, that the variation in the consumption of the food commodities is significant in the 3 independent variables.

Maha (1999) providẹd a study on consumption and means of rationalizing itin different fields, in addition to highlighting on consumer's behavior and the factors driving consumption. The study resulted was peiformed in a form of a questionnaire and resulted in different methods enforcing rationalizing consumption especially in food and clothes.

Eman (2006) provided a study on the reasons behind the changes that appeared in the consumption culture, by introducing social, economic, political and legal awareness for the Egyptian 
society: She performed a field study to search for the various reasons that participated in the change of the consumption culture for the society under investigation Benha University. The result showed the existence of a correlation between: each of: gender or sex, age, educational / level, professional level social status, amount of income and the change of the culture of consumption in the society, under investigation. In additions it resulted that there is a group of factors affecting the change of the culture of consumption in the society as: the successive economic policies, globalization, openness towards the foreign world, change of income's level, mass media and recent / modern means of communication and technology.

Rabi (2006) presented a theoretical study concerned with consumption behavior and factors influencing it, in addition to fields of Rationalizing family consumption and the role of the community agencies in promoting the culture of Rationalizing consumption. This study enriches the theoretical field of consumption and it benefits in the formulation of a questionnaire as a tool to collect data in this research:

Nagah (2008) showed the brilliant sides of Islamic economics and comparing the Islamic economics with conventional one in addition to determining the different means in protecting. the consumer in the Islamic economics. The study uses the historical method to show the facts about consumer protection and uses comparative method to compare between Islamic and conventional economics. The study revealed that despite that Islamic economics and Convention: 1 economics agreed on the necessity of protecting the consumer from the harms that might affect him, also it indicated that the Muslim consumer showed be attached to shari'ah principles.

Norah (2010) used the descriptive and historical method to show the Islamic foundations. The importance of the study is presented. 
in elaborating the significant role of globalization in spreading the culture of consumption between broad sectors of individuals and populations in all countries as a general and in the developing countries in specific: Although studies have been made to study consumption pattern in Egypt, and conventional Economics theories have provided assistance to adjust consumption pattern but little studies have been done to study consumption pattern in Egypt according to Islamic Economics. Moreover, adding "Rushd" element (Rationality) in studying the Egyptian consumption through encouraging moderate living standard as neither extravagant. nor niggardly but balancing between them according to shariah principles, will enhance having a justly balanced nation, which will consequently improve Egypt's effectiveness, and efficient in utilizing its resources in the short-run on one hand and fastening its path on developmeñt in the long-run.

Amal (2014) aimd to understand attitudes of Saudi university student towards the "awareness of the rational consumption culture and the sources of this awareness. The study performed a questionnaire on a sample consisting of 550 female students from the department of social studies at the University studies for girls' center in king Saud University. The statistical treatment of the study indicated the presence of statistical relationship between the social background of the student and the knowledge of rational consumption culture and the practice of this culture. And it ended with some recommendations at the level of university, community and family.

\section{Importance of the study:}

1. To highlight the meaning, strengths and implications of "Rationalism" that is inherent in the Islamic World view.

2. To examine Conventional Consumption strengths; weaknesses and threats in order to be able to provide Islamic critics on these Conventional approaches of Consumption. 
3. This study indicates the relative importance of "Islamic Rationalism" element in Moderating Consumption pattern.

4. Understanding Consumption pattern in Egypt.

5. The output of this study could assist policy makers to formulate new consumption pattern model to face consumption challenges in Egypt.

\section{Study Limitations:}

Time limitations: the study covers the period starting from year 2000 due to the changing in consumer taste as an impact of overwhelming globalization.

Place limitations: the study is concerned with Egypt.

\section{Objectives of the Study:}

1. Understanding Consumption pattern in Egypt.

2. Presenting "Islamic Economics" as an alternative to existing economic doctrines and systems.

3. Designing an Islamic Consumption Framework that may be applicable in Egypt.

4. Using the suggested framework to develop Islamic theory of consumer behavior, which will add the concept of "Rushd" (as opposed to the concept of Rationality) in secular Economics) in adjusting the Consumption pattern in Egypt.

\section{Study Hypotheses:}

1. Islamic rational consumption is more comprehensive than Conventional Rational Consumption:

2. Egypt is suffering from ex:avagance spending.

3. Consumption level in Egypt will be lower if islamic Rational Consumption is applied. 
47Dr. KHoloud Hossam - Dr. Nahed Helmy - Applying Islamic Rational Consumption

\section{Methodology of the study:}

The research will investigate the impact of applying Islamic Rationality on Consumption in Egypt by using econometric method.

\section{Data Sources:}

To measure the impact of applying Islamic Rationality on Consumption in Egypt whereby the data for Income, Expenditure and Consumption is available from the CAPMAS (Central Agency for Public Mobilization and Statistics) through the survey published named "Income, Expenditure and Consumption", in addition other data as Poverty and Investment are available through the CAPMAS website.

The final selected data for the study since year 2000 as the Egyptian consumer has been deprived of choice for a longtime and at the beginning of 2000, the Egyptian consumer starts to demand new products and equipment in the face of globalization and offers good outlets for foreign.

\section{Empirical Framework:}

This study uses deductive methods to analyze Conventional Consumption situation in Egypt and the effects of applying Islamic Rationality on it. Also, it uses an econometric model which will be conducted to know whether Rationality in an Islamic perspective could affect theConventional Consumption.

The linkage between Islamic Rationality and Consumption can be viewed in terms of the following hypothesis: Islamic Rationality has a positive impact on Consumption. Consequently, Consumption is the dependent variable while Islamic Rationality and other factors are independent variables. 
Panel data are a type of longitudinal data, in other words two or more observations that are collected on many units at different points of time

Panel data tends to have several advantages over crosssectional data and time-series data, as:

Greater capacity for capturing the complexity of human. behavior than a single cross-section or time series data

Simplifying computation and statistical inference whereby, it involves at least two dimensions, a cross-sectional dimension and a time series dimension.

Allowing control for omitted (unobserved or mis measured) variables.

Giving more informative data, more degrees of freedom, more variability, less collinearity among variables, more variability

In this section the researcher Nahed apply the procedure of the multiple linear regression using the ordinary least squares (OLS) method and two robust regression methods: Least Trimmed Square (LTS) and M - Estimation in SAS and R programs on both the urban and the rural sectors to compare between the three methods. The path analysis in AMOS program for both urban and rural sectors are obtained. It is interested with some variables such as the economic sector, the education status, the family size and the total annual income which affecting the total expenditure. This study is concerned with determining the shape of the distribution of the total annual income before and after removing the outliers from the data of the income using the classical measures of skewness and kurtosis: $B_{1}, B_{2}$ and robust measures of skewness and kurtosis. It is concerned with calculating the zakat. Also, it is interested in the method to allocate the income between the expenditure groups. 
The dependent variable is the total expenditure for the family denoted by $Y$ which is affected by the selected following independent variables: the economic sector for the family denoted by $X 1$, the education status for the family denoted by $X 2$; the family size denoted by $X 3$ and the income denoted by $X 4$. The data used in the present paper is obtained from the row data of the income, expenditure and consumption data for the year 2015 from the central agency for public mobilization and statistics(CAPMAS). The total data is divided into urban and rural sectors to compare between them. A sample of 600 objects is selected from each sector to be used in this paper. It is suggested to apply the ordinary least squares and two of the robust regression methods: the trimmed least squares and the $M$ - estimation and compare between the three methods using both the standard error and the $\mathrm{R}$ - square measure obtained. When the trimmed least squares method is applied the outliers, which found in the data are removed then the weighted least squares method is applied. The three methods are applied on the data using both SAS and R programs. The total results are obtained in the: appendix.The standard error for the variables under study which are obtained when applying the three methods for urban data are given in table (1). 
Table (1): the results from applying the three methods for urban and rural sectors

\begin{tabular}{|c|c|c|c|c|c|c|c|c|}
\hline \multirow{2}{*}{$\begin{array}{c}\text { Method } \\
\vdots \\
\end{array}$} & & \multicolumn{5}{|c|}{ Standard error for the estimates of coefficients } & \multirow[t]{2}{*}{$R^{2}$} & \multirow{2}{*}{$\begin{array}{l}\text { Proporti } \\
\text { on of } \\
\text { outlier }\end{array}$} \\
\hline & & intercept & $B_{1}$ & $B_{2}$ & $B_{3}$ & $B_{4}$ & & \\
\hline \multirow[t]{2}{*}{ OLS:" } & $\begin{array}{c}\text { Urba } \\
n\end{array}$ & 3442 & 21.87 & 448.2 & $\begin{array}{c}547.8 \\
\vdots\end{array}$ & $\begin{array}{l}0.0058 \\
25 \\
\end{array}$ & $\begin{array}{c}0.880 \\
5\end{array}$ & - \\
\hline & $\begin{array}{c}\text { Rura } \\
1\end{array}$ & \begin{tabular}{|c|}
2633.381 \\
63 \\
\end{tabular} & $\begin{array}{c}18.239 \\
61 \\
\end{array}$ & $\begin{array}{c}366.229 \\
29 \\
\end{array}$ & $\begin{array}{c}401.156 \\
13 \\
\end{array}$ & $\begin{array}{c}0.0521 \\
1\end{array}$ & 0.421 & - \\
\hline \multirow{2}{*}{$\begin{array}{l}\text { Final } \\
\text { weighte } \\
\text { d least: } \\
\text { squares } \\
\text { (LTS) }\end{array}$} & $\begin{array}{c}\text { Urba } \\
n \\
?\end{array}$ & $\begin{array}{l}1022.018 \\
\ldots\end{array}$ & 6.4538 & $\begin{array}{c}144.595 \\
6\end{array}$ & $\begin{array}{c}165.584 \\
9\end{array}$ & 0.0146 & $\frac{0.825}{8}$ & $8 \%$ \\
\hline & $\begin{array}{l}\text { Rurat } \\
. \quad \mathrm{I}\end{array}$ & $\begin{array}{l}1080.071 \\
.\end{array}$ & 7.212 & $\begin{array}{c}146.930 \\
6\end{array}$ & $\begin{array}{c}165.214 \\
8\end{array}$ & 0.0266 & $\begin{array}{c}0.781 \\
5\end{array}$ & $9.67 \%$ \\
\hline \multirow{2}{*}{$\begin{array}{l}\therefore \mathrm{M}- \\
\text { estimati } \\
\because \text { on } \\
\because\end{array}$} & $\begin{array}{l}\text { Urba } \\
\cdot \mathrm{n} \\
\end{array}$ & 1058.008 & 6.7243 & $\begin{array}{c}137.780 \\
8\end{array}$ & $\begin{array}{c}168.394 \\
3 \\
\end{array}$ & 0.0018 & 0.578 & $8.6 \%$ \\
\hline & $\begin{array}{c}\text { Rura } \\
1\end{array}$ & 1104.325 & 7.6489 & $\begin{array}{c}153.580 \\
5 \\
\end{array}$ & $\begin{array}{c}168.227 \\
3 \\
\end{array}$ & 0.0219 & $\begin{array}{c}0.504 \\
5\end{array}$ & $9.33 \%$ \\
\hline
\end{tabular}

". "These calculations are made by the researcher

It is noticed that the standard error for the intercept and the independent variables has the smallest value when the LTS 'method is 'applied then the $\mathrm{M}$ - estimation method then the OLS method except for the last independent variable in the two "sectors. In' addition, the $R$ - squared measure has the largest value for the LTS method than the two methods the OLD and the $\mathrm{M}$-estimationand urban sector has larger value than rural sector in the three methods.

The scale parameter $\sigma$ is usually unknown. In LTS method the median absolute deviation, $w$, is defined by:

$$
\left(\left|X-x_{0.5}\right| \leq w\right)-0.5
$$

In otherwords, $w$ is the median of the distribution associated with $\left|X-x_{0.5}\right|$, the distance between $X$ and its median.

It is suggested to represent the relation between the dependent variable and the independent variables using the path analysis in AMOS program. 


\section{Path analysis for urban data is given in figure (1).}

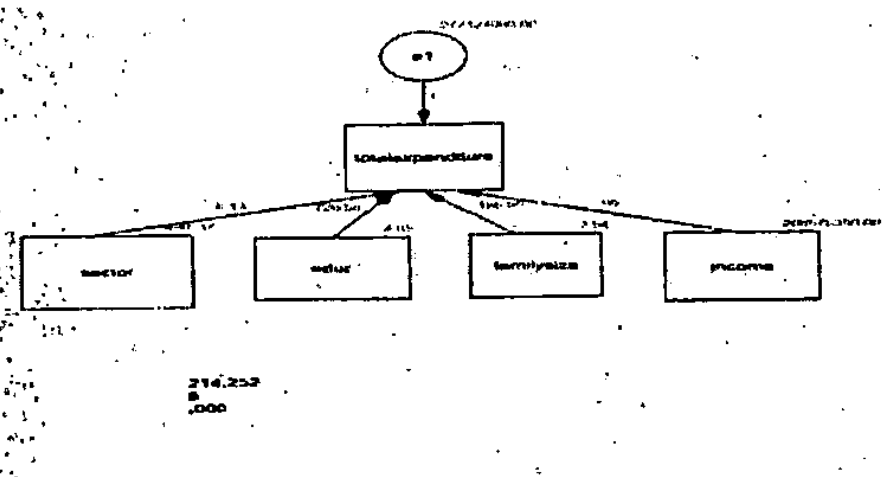

$\therefore$ Figure (1): path analysis for urban data which is made by the researcher

Since the $p$-value for the urban sector is equal to 0.01 which less than the level of significance $\alpha=0.05$ so that the model is fitting well.

Path analysis for rural data is given in figure (2).

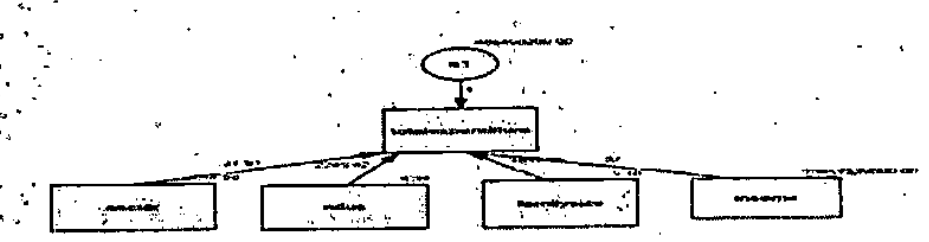

sions...;

Figure (2): path analysis for rural data which is made by the researcher

Since the $p$-value for the rural sector is equal to 0.01 which less than the level of significance $\alpha=0.05$ so the model is fitting well.

The values for both the two measures of goodness of fit $A I C$ and $B I C$ are given in table (2). It is noticed that the goodness of fit is satisfied at the lowest value for these measures.

Table.(2): the values of $A I C$ and $B I C$

\begin{tabular}{|c|c|c|c|}
\hline & AIC & BIC & CR \\
\hline Urban sector & 181.797 & .221 .369 & 17.306 \\
\hline Rural sector & 232.252 & 271.825 & \\
\hline
\end{tabular}

"These calculations are by the researcher 
It is noticed the measure CR (regression weight estimated by the estimate of its standard error) is equal to 17.306 which is greater than 1.964 so it means that the model of regression fits well. The two measures for goodness.of fit AIC and BIC for the urban sector is less than for the rural sector so it is the best fitting for the empirical distribution of the data under study.

It is suggested to study the shape of the distribution of the income data for both urban and rural sectors using the skewness and the kurtosis measures.

The Hinkley (1975) coefficient for measuring' the skewness (which is robust against outliers) is given by:-

$$
s \dot{c}=\frac{\left(Q_{1-p}-Q_{0.5}\right)-\left(Q_{0.5}-Q_{p}\right)}{\left(Q_{1-p}-Q_{p}\right)}
$$

where $Q_{p}(0<p<0.5)$ is the $p^{\text {th }}$ quantile of the random variable $X$. It is noticed that as the value of $p$ increased the value of the measure of skewness $S C$ decreased. It is suggested to use $p=$ 0.2 since there are outliers in the income data which is skewed to the right.

The Hogg (1974) coefficient for measuring the kurtosis (which is robust against outliers) is given by:

$$
K C=\frac{Q_{1-p}-Q_{p}}{Q_{1-q}-Q_{q}}
$$

where $0<P<q<0.5$ and $Q_{p}$ denotes the $p$ - quantile of the distribution. It is noticed that as the value of $p$ increased the value of the measure of kurtosis $K C$ increased. It is suggested to use $p=0.2$.

The results for both the skewness and the kurtosis measures before removing outliers and after removing them are given in table (3) using Mathcad program. 
Box plot is used to determine the outliers in the data of the income using SPSS program. It is found that 12individuals are considered as outliers (\%2) in each urban and rural sector.

Table (3): the values of both the skewness and the kurtosis measures for urban and rural sectors

\begin{tabular}{|c|c|c|c|c|c|}
\hline & & & & $\begin{array}{c}\text { Robust } \\
\text { skewness ( }\end{array}$ & $\begin{array}{c}\text { Robust } \\
\text { kurtosis ( }\end{array}$ \\
\hline \multirow{2}{*}{ urban } & Full sample & 19.22 & 427.86 & 0.219 & 1.566 \\
\cline { 2 - 6 } & Reduced sample & 1.634 & 3.656 & 0.178 & 1.537 \\
\hline \multirow{2}{*}{ rural } & Full sample & 1.502 & 3.476 & 0.176 & 1.63 \\
\cline { 2 - 6 } & Reduced sample & 1.221 & 1.679 & 0.132 & 1.582 \\
\hline
\end{tabular}

These calculations are by the researcher

It is noticed that the distribution of the data of the income for both urban and rural sectors is skewed to the right since the values of the $B_{1}$ and $S C$ are positive. In addition, the value of the skewness measure is decreased after removing the outliers from the data but these values are bigger in urban sector than in rural sector. It is noticed that the values of $\mathrm{B}_{2}$ for both full sample in urban and rural sectors and in reduced sample in urban sector are greater than 3 (the distribution of the data is Leptokurtic). For reduced sample in rural sector the value of $B_{2}$ is less than 3 (the distribution of the data for the income is called platykurtic). On the other hand, the value of $\mathrm{KC}$ is bigger in rural sector than in urban sector and less than 3 ( the distribution of the data is platykurtic).

Location and scale measures for the income data for the full and reduced sample for urban and rural sectors are given in table (4) 
Table (4): location and scale measures for the income data for the full and reduced sample for urban and rural sectors

\begin{tabular}{|r|c|c|c|c|c|}
\hline & & mean & Median & $\begin{array}{c}\text { Ständard } \\
\text { deviation }\end{array}$ & IQR \\
\hline urban & $\begin{array}{c}\text { Full } \\
\text { sample }\end{array}$ & 53631.4524 & 39266.56 & 153937.7281 & 14546.5625 \\
\cline { 2 - 6 } & $\begin{array}{c}\text { Reduced } \\
\text { sample }\end{array}$ & 44326.6882 & 38942.28 & 26855.11857 & .14243 .5625 \\
\hline rural & $\begin{array}{c}\text { Full } \\
\text { sample }\end{array}$ & 29875.8947 & 27443.25 & 14454.18814 & 7571.01 \\
\cline { 2 - 6 } & $\begin{array}{c}\text { Reduced } \\
\text { sample }\end{array}$ & 28733.1968 & 27287.5 & $\ddots$ & 7146.125 \\
\hline
\end{tabular}

These calculations are by the researcher

From table (4) it is noticed that the median is lower than the mean which indicates no symmetry of the distribution. As for the measures of scale the standard deviation dropped greatly compared to the interquartile range which indicates the sensitivity of the standard deviation to outliers. Measures of location and scale are almost the same for rural and urban sectors.

The present paper is concerned with a trial to distribute the annual total income on the expenditure groups. To do this it is suggested to calculate the ratio of each group of the expenditure groups to the total groups, then multiplying the total income by each ratio. The total income for rural is 38305.1 . The results of these calculations for the rural sector are given in table (5). 
55Dr. KHoloud Hossam - Dr. Nahed Helmy - Applying Islamic Rational Consumption

- Table (5): the ratio of the expenditure groups for rural sector

\begin{tabular}{|c|c|}
\hline $\begin{array}{l}\text { The ratio of } \\
\text { each group }\end{array}$ & The share of each group from the income \\
\hline 0.41 & 15830.3 (Food and Non-Alcoholic Beverages) \\
\hline 0.06 & 2472.8 (Clothing and Foot wear) \\
\hline 0.17 & 6423.7 (Housing, Electricity, Water, Gas andother Fuels) \\
\hline 0.04 & $\begin{array}{c}\text { 1699.6 (Furnishings, H.H equipment and routine H.H } \\
\text { maintenance) }\end{array}$ \\
\hline 0.11 & 4050.0 (Health) \\
\hline$\because 0.05$ & 2091.9 (Transport) \\
\hline 0.02 & 795.1 (Communication) \\
\hline 0.02 & 787.0 (Recreation and Culture) \\
\hline $0: 03$ & 1291.9 (Education) \\
\hline$\quad 0.03$ & 1309.1 (Restaurants and Hotels) \\
\hline 0.04 & 1515.4 (Miscellaneous goods and services) \\
\hline
\end{tabular}

*These calculations are by the researcher.

It is noticed that the group of expenditure for the food and non - alcoholic beverages has the largest value.

The total income for urban is 51178.8 . The results for the urban sector are given in table (6). 
Table (6): the ratio of the expenditure groups for urban sector

\begin{tabular}{|c|c|}
\hline $\begin{array}{l}\text { The ratio of each } \\
\text { group }\end{array}$ & The share of each group from the income \\
\hline 0.03 & 366.76 (Food and Non-Alcoholic Beverages) \\
\hline 0.05 & 633.28 (Clothing and Foot wear) \\
\hline 0.19 & 2293.92 (Housing, Electricity, Water, Gas \& other Fuels) \\
\hline 0.04 & $\begin{array}{l}480.34 \text { (Furnishings, H.H equipment and routine H.H } \\
\text { maintenance) }\end{array}$ \\
\hline 0.10 & 1215.48 (Health) \\
\hline 0.08 & 886.43 (Transport) \\
\hline 0.03 & 351.57 (Communication) \\
\hline 0.02 & 261.85 (Recreation and Culture) \\
\hline 0.24 & 2722.44 (Education) \\
\hline 0.05 & 569.62 (Restaurants and Hotels) \\
\hline 0.04 & 480.83 (Miscellaneous goods and services) \\
\hline
\end{tabular}

-These calculations are by the researcher

It is noticed that the group of expenditure for education has the largest value. The individuals in the data obtained from the central agency for public mobilization and statistics(CAPMAS). it is suggested to calculate the median of the total annual income for each individual in both urban and rural sectors in which the individuals which have incomes under this median are considered poor and the individuals which have incomes above this median are considered nonpoor. To calculate the Zakah, it is suggested to multiply the total income of the individuals who are nonpoor by $\% 2.5$ and add the obtained value to the total income of the individuals who are poor in both urban and rural sectors. Since each individual has the code 1 or 0 in both the data of urban and rural sectors at 2015 . Code (1) means that the individual is poor and code $(0)$ means that the individual is nonpoor. It is suggested to divide these individuals into two groups. One group contains the individuals who have the code (1) which are considered poor 
and the other group contains the individuals who have code (0) which are considered nonpoor. To calculate the Zakah, it is suggested to multiply the total income of the individuals who are nonpoor by $\% 2.5$ and add the obtained value to the total income of the individuals who are poor in both urban and rural sectors.

\section{Statement of the Problem}

As mentioned above (in the introduction), that "Rationality". Principle in "Rational Consumption" is discussed from 2 different perspectives, from Conventional Economics perșpective and from Islamic Economic ones. Since it is mentioned that islamic Rational consumption is more comprehensive that conventional one, thus here there is an arising question which is: Why Islamic Rational Consumption?Thus, the question can be answered through comparing the worldview of the two systems and then elaborating the benefits of Islamic Rational Consumption and then concluding the preferable and most appropriate one of them:

Table (7) Comparison between: Islamic Rational Consumer and Conventional Rational Consumer

\begin{tabular}{|c|c|c|}
\hline Points of Comparison & Islamic Rational Consumer & $\begin{array}{c}\text { Traditional Rational } \\
\text { Consumer }\end{array}$ \\
\hline Similarities & \multicolumn{2}{|c|}{$\begin{array}{c}\text { - In both cases a rational consumer is the one who is } \\
\text { neither a miser nor a spendthrift }\end{array}$} \\
\hline $\begin{array}{l}\text { Meaning of the term } \\
\text { "Rational Consumer" } \\
\vdots \\
\vdots\end{array}$ & $\begin{array}{l}\text { An Islamic Rational consumer } \\
\text { is the one who is not against } \\
\text { the principles of Islam, who } \\
\text { strongly believes in Islamic } \\
\text { Shariah, aiming to spend in } \\
\text { moderation, so he is neither } \\
\text { extravagant nor miser for both } \\
\text { worldly life and hereafter life. }\end{array}$ & $\begin{array}{l}\text { Refers to an individual } \\
\text { whose main target is } \\
\text { to achieve maximum } \\
\text { satisfaction through } \\
\text { spending his way, } \\
\text { even if he allocated a } \\
\text { portion of his incorne } \\
\text { to consume alcoholic } \\
\text { beverages. }\end{array}$ \\
\hline Positive,Economics & Included & Motivated \\
\hline
\end{tabular}

Source: Information collected by the researcher from different sources 


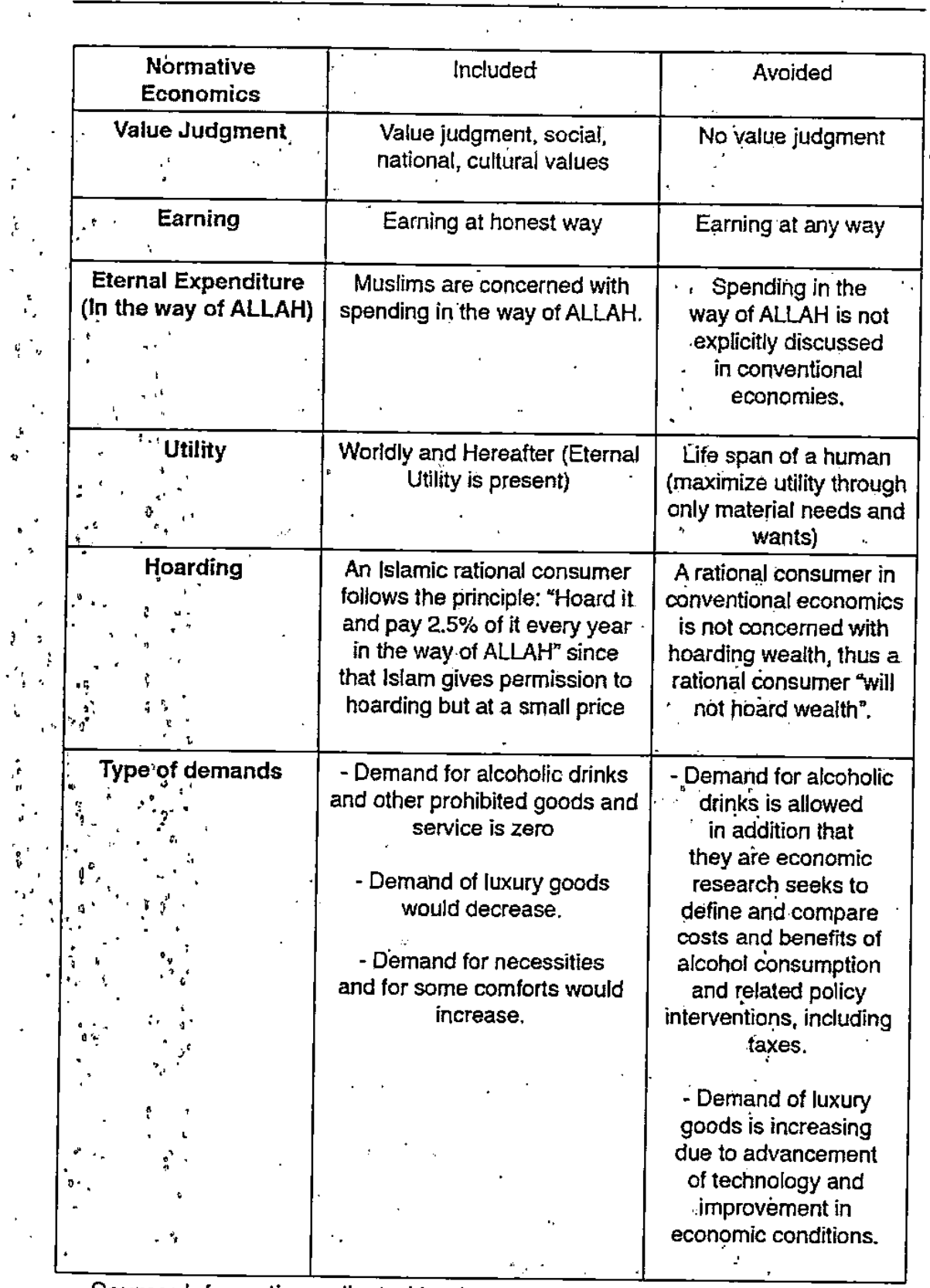

Source: Information collected by the researcher from different sources 
59́Dr. KHoloud Hossam - Dr. Nahed Helmy - Applying Islamic Rational Consumption

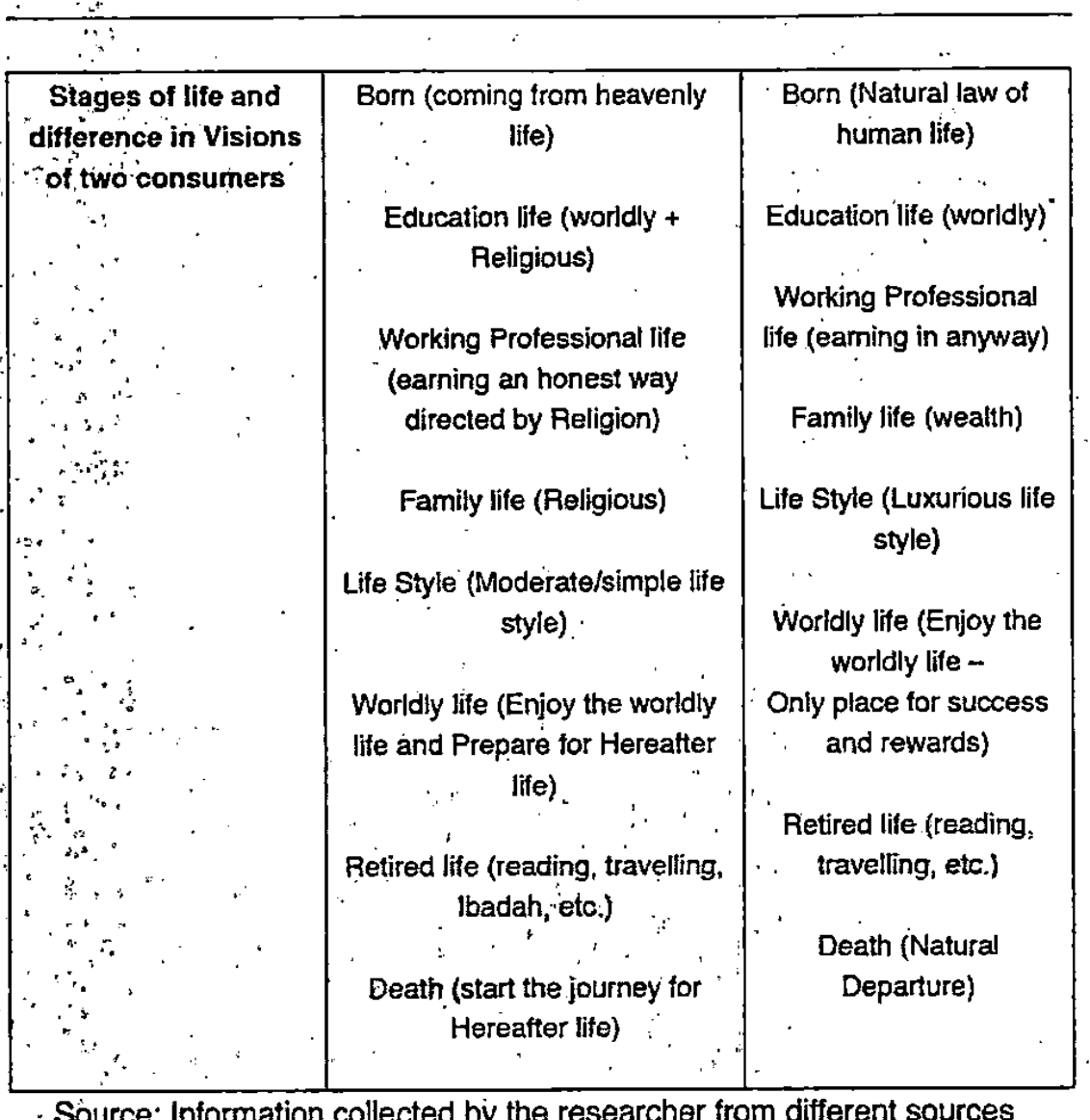

$\because \quad$ Source: Information collected by the researcher from different sources

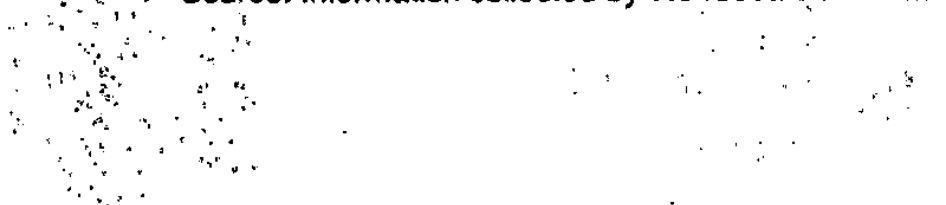




\begin{tabular}{|c|c|c|}
\hline $\begin{array}{l}\text { Characteristics of } \\
\text { Rational consumer }\end{array}$ & $\begin{array}{c}\text { The key assumptions are as } \\
\text { follows: } \\
\text { 1- Consumer behavior is } \\
\text { based on Islamic Economic } \\
\text { Rationalism and fear of ALLAH. } \\
\text { 2-An Islamic Consumer } \\
\text { strongly believes in lslamic } \\
\text { Shariah. } \\
\text { 3-A consumer is regarded } \\
\text { as economic and moral utility } \\
\text {. maximizer. } \\
\text { 4- He can control his wants as } \\
\text { well as demand. } \\
\text { 5- Utility or satisfaction derived } \\
\text { from worldly and Heavenly. } \\
\text { 6- He only Consumes useful } \\
\text { while avoid harmful goods and } \\
\text { services, for himself and for } \\
\text { whole society. } \\
\text { 7- Spend in moderation neither } \\
\text { as miser nor extravagant, both } \\
\text { for here (Worldly) and hereafter } \\
\text { (Heavenly). } \\
\text {. } \\
\text { 8- Strictly consider Halal and } \\
\text { Haram in consumption. } \\
9-\text { He does not hoard his } \\
\text { wealth }\end{array}$ & $\begin{array}{l}\text { The rational consumer } \\
\text { is ethical when: } \\
\text { 1- His spending is fairly } \\
\text { done even through } \\
\text { borrowing. } \\
\text { 2- His spending is } \\
\text { justified albeit for the } \\
\text { appetence desires. } \\
\text { 3- He is not encouraged } \\
\text { to borrow even if the } \\
\text { bank interest rate is not } \\
\text { high } \\
\text { 4- He adheres to not } \\
\text { spending money in } \\
\text { illegal products and } \\
\text { services although his } \\
\text { spiritual emptiness } \\
\text { pushes him/her to } \\
\text { acquire the forbidden. }\end{array}$ \\
\hline
\end{tabular}

Source: Information collected by the researcher from different sources 
61 Dr. KHoloud Hossam - Dr. Nahed Helmy - Applying Islamic Rational Consumption

\section{Comment on the above-mentioned table:}

\section{It can be concluded that:}

It highlighted some of the weaknesses in Conventional Economics as: avoiding normative economics, principle of selfinterest, focuses only on worldly life, spending could be done through borrowing, and social and moral values are absent, can consume any kind of goods.

- It highlighted some of the strengths in Islamic economics as: including normative economics; encourages the welfare of the society, takes into consideration worldly life and hereafter life, motivating spending in the way of the ALLAH, and encourages the presence of social and moral values, consume only halal and prohibits Haram.Therefore, the question is answered by highlighting the strengths of Islamic rational consumption and that rationality is a situation between extravagance and niggardly. Thưs, by elaborating the Egyptian case study, it can be seen that since 1990, a rapid shift in household consumption occurred Egypt, a new consumption culture has been drawn in Egypt, mainly due to globalization. An overwhelming new lifestyle has been drawn in Egypt to drawn demand attention, for instance Cairo alone includes more than 24 shopping malls huge number of supermarkets- offering everything you can imagine, fâncy restaurants, the spread of mobile telephones and coffee shops, plastic surgery and the body. Thus, despite the fact that, household final consumption expenditure is formulating a major component in the GDP formula in Egypt- where by it is increasing until it reached \%82.24 in 2015 and that the share of Egyptian Household expenditure in the public budget increased in the "financial year $2015 / 2014$ by 3 times more than the financial year 2008/2007.Still, in terms of prosperity and Welfare, Egypt ranked as the second least prosperous country in North Africa, where by 
it ranked $117^{\text {th }}$ (out of 149 country) on the "Legatum Prosperity Index"52 in 2016. Moreover, by looking at the "Prosperity Gap"11), it is found out that since 2013 Egypt is suffering from prosperity index close by \%27. Thus, it is evident that despite the high percentage spent on consumption from GDP, still Egypt suffering from lack of prosperity and welfare. Thus, the arising question here is: what is the defect that is occurring in the Egyptian Consumption pattern that deprives Egypt from enjoying prosperity, welfare and good quality of life?By viewing the relative distribution for average per capita of family annual expenditure by major expenditure groups by tens categories of Egypt total in 2015, we will find out that:

Table (8): The Relative distribution for average per capita of family annual expenditure by major expenditure groups by categories in Egypt total in Year 2015

\begin{tabular}{|l|c|}
\hline Expenditure Groups & $\begin{array}{c}\text { Percentage (\%) of Total } \\
(100)\end{array}$ \\
\hline Food and Non-Alcoholic Beverages & 34.4 \\
\hline $\begin{array}{l}\text { Housing, water, electricity, gas and other } \\
\text { fuels }\end{array}$ & 17.5 \\
\hline Health & 10.0 \\
\hline Transport & 6.3 \\
\hline Clothing and Footwear & 5.6 \\
\hline Education & 4.8 \\
\hline Alcoholic Beverages, Tobacco and Narcotics & 4.7 \\
\hline $\begin{array}{l}\text { Furnishings, H.H equipment and routine } \\
\text { H.H maintenance }\end{array}$ & $\ddots$ \\
\hline Restaurants and Hotels & 4.1 \\
\hline Miscellaneous goods and services & 4.0 \\
\hline Communication & 3.9 \\
\hline Recreation and Culture & 2.5 \\
\hline
\end{tabular}

Source: CAPMAS, "Annual statistical book 2015", Section (22), (Public indicators: Income, Expenditure and Consumption survey 2015), pp. 9-6

(1) "Prosperity Gap": "takes a country's GDP and uses it as the yardstick to measure a nation expected Prosperity. Index ranking. 
63 Dr: KHoloud Hossam - Dr: Nahed Helmy - Applying Islamic Rational Consumption

By analyzing the above table, it is clear that the 3 major components in the household consumption are: Food and NonAlconholic Beverages with \%34.4, then the second component is: Housing, water, electricity, gas and other fuels with \%17.5. and the third one is Health with \%10.Thus, to better analyze Consumption pattern in Egypt, main components formulating thoúsehold consumption should be examined.

1 . Component: Concerning Food Expenditure:

$\because$ Although Egyptians are considered as big speñders and food consumers, also food expenditure is a major component in household spending, still Food consumption in Egypt suffering from problems. One hand, by looking at the dietary energy consumption per person in Egypt, it is found out for 'instance in 2007, Egypt recorded 3,160 calorie intakes perday where by the required calories per day to maintain are about 2000 calories $\because$ per day for average woman and about 2500 calories per day for $\therefore$ average man.On the other hand, FAO found out that Egypt has $\therefore$ an increasing rate of food losses and waste, whereby wastes and

$\therefore$ Jósses reached:

$\because$ Táble (9): Percentages of food losses and waste in Egypt in 2015

$\because$

\begin{tabular}{|c|c|c|c|}
\hline Item & Vegetables and fruits & Fish & Milk \\
\hline Percentage of food losses and waste & $50 \%$ & $40 \%$ & $30 \%$ \\
\hline
\end{tabular}

Source: Gehan elmenofi, Roberto Capone, Francesco Bottalico, Hamid El

$\because$ Bilali, "An exploratory survey on household tood waste in Egypt"; October

r. : 20ं15, research gate, Page 1298

Moreover, the economic loss resulted from food wastes reàched .1.5.million tons/per annum in wheat and about 11 million EGP/ $\because$ annually in wheat, tomato and orange. In addition, a questionnaire was performed to introduce the concept of food losses and.waste - its total sample size is 181 adults Egyptian - "found out the following results: 
Table (10): Respondents estimation for purchased food groups wastage (In Percentage)

\begin{tabular}{|c|c|c|c|c|c|}
\hline Items & $\begin{array}{c}\text { Less than } \\
.2 \%\end{array}$ & $\begin{array}{c}3 \text { to } \\
5 \%\end{array}$ & $\begin{array}{c}6 \text { to } \\
10 \%\end{array}$ & $\begin{array}{c}\mathbf{1 1} \text { to } 20 \\
\%\end{array}$ & $\begin{array}{c}\text { Over } \\
\mathbf{2 0} \%\end{array}$ \\
\hline $\begin{array}{c}\text { Cereals and bakery } \\
\text { products }\end{array}$ & $63.5 \%$ & $19.3 \%$ & $.9 .9 \%$ & $0.6 \%$ & $6.6 \%$ \\
\hline Roots and tubers & $75.7 \%$ & $14.9 \%$ & $4.4 \%$ & $3.3 \%$ & $1.7 \%$ \\
\hline Pulses and oil seeds & $84.0 \%$ & $11.0 \%$ & $2.2 \%$ & $1.1 \%$ & $1.7 \%$ \\
\hline Fruits & $75.1 \%$ & $14.9 \%$ & $5.0 \%$ & $1.7 \%$ & $3.3 \%$ \\
\hline Vegetables & $65.7 \%$ & $19.9 \%$ & $9.9 \%$ & $1.7 \%$ & $2.8 \%$ \\
\hline Meat and meat products & $93.4 \%$ & $2.8 \%$ & $1.7 \%$ & $1.7 \%$ & $0.6 \%$ \\
\hline Fish and seafood & $91.2 \%$ & $6.6 \%$ & $1.1 \%$ & $0.6 \%$ & $0.6 \%$ \\
\hline Milk and dairy products & $81.8 \%$ & $12.2 \%$ & $3.3 \%$ & - & $2.8 \%$ \\
\hline
\end{tabular}

Source: Gehan eimenofi, Roberto Capone, Francesco Bottalico, Hamid EI Bilali, "An exploratory survey on household food waste in Egypt", October 2015, research gate, Page 1302

It is showed in the above table the percentage of food waste in Egypt in 2015. Thus, Aggregate food Consumption in Egypt is high in addition it is evident that some Egyptians are suffering from Extravagance spending.To sum up, it is clear that food. expenditure problem is that Egyptians is extravagance spending.

$\underline{2}^{\text {nd }}$ Component: Concerning Housing, water, electricity, gas and other fuels:

Turning to the $2^{\text {nd }}$ major component formulating household expenditure, it is found out that: on one hand, water supplies and available water resources tend to decrease; as shown in the following table:

Table (11): Decreases of the yearly water shape per capita in Egypt over a century

\begin{tabular}{|c|c|c|c|c|c|c|c|c|c|}
\hline year * & 1897 & 1927 & 1947 & 1960 & 1970 & 1986 & 1993 & 2000 & 2015 \\
\hline $\begin{array}{c}\text { Water quantity } \\
\text { per Capita }\left(\mathrm{m}^{3}\right)\end{array}$ & 5084 & 3484 & 2604 & 1893 & 1713 & 1138 & 981. & 957 & 663 \\
\hline
\end{tabular}

Source: Rasha El Gohary, "Agriculture, Industry and Wastewater in the Nile Delta", International Journal of Sciéntific Research in Agricultural sciences, 2015, page 159. 
On the other hand, still water demand continues in increasing due to pressures put on water resources as rising pressure due to population growth, rapid urbanization, acceleration of economic and demographic development, farmers preference of using flood irrigation in new land regardless of exploring new irrigation systems. Moreover, the Nile River is receiving a large quantity of industrial, agriculture and domestic wastewater. It is worth to mention that the water pollution is a kind of water waste and it can be caused by either natural effect or by human intervention. Along the river there are' about 700 industrial facilities, and many industries are causing wastes into the Nile River.In spite of consuming the agriculture sector of $\% 85$ of total demand for water, it contributes of only about \%20 in the GDP. In addition, although it is evident that there is extravagance spending in agriculture, the wheat accounted for almost \%32:6 of the total imports bill in 2013 . Moreover, other, Egyptians are suffering from uneven distribution of water, for instance, since that some farmers are misusing water resources and already water resources are scarce. Also, despite that water cóverage supply is increasing still sanitation services lagging "behind. Thus, it is evident that there is gap as water supply is decreasing and water demand is increasing in addition to human intervention which is participating in wasting large quantities of water, so some Egyptians are suffering from Extravagance speriding in water.Turning to gas expenditure, on one hand, for the fiscal.year 2015/2014 it is found out that in gas oil for instance, despite that Egypt was the $25^{\text {th }}$ world's largest oil producer, representing \%0.3 of the global total (in year 2010), it has become increasingly dependent on importing oil products, totaling as much as $1.3 \$$ billion per month (almost 15.6 billion $\$$ per year out of total allmost less than $5000 \$$ million during 2015). Thus, there is extravagance spending in gas in Egypt.To sum up, it is clear that some extracts of gas expenditure in Egypt as oil is suffering extravaganice spending. 


\section{$3^{\text {rd }}$ Component: Concerning Health Expenditure:}

Although; total expenditure of health improved to reach \%5.6 of GDP in 2014. Moreover, according to CAPMAS; expenditure on health is increasing as income increases, whereby at the top income level expenditure spent on healthcare reached \%10.6 of income in 2015 while for average Egyptian family \%9.2 of income is spent annually on healthcare. Also, according to Central Bank to Egypt, per capita government spending on health is 108 (PPP int. USD). Still, health expenditure has some weaknesses. As despite the high caloric intake, by some Egyptians, still the Egyptian individual suffering from triple burden of malnutrition (obesity, stúnting and micronutrient deficiencies (anemia) and unbalanced essential food elements like energy; protein, and fat content. Moreover, \%35.1 of total population in 2011 , were found to be suffering from poor dietary diversity, where by this rate reached almost \%58.3 in the low-level income. (Poor Egyptians).Although, Health expenditure in the $3^{\text {rd }}$ item on the Relative distribution for average per capita of family annual experiditure in year 2015, still nearly \%50 of Egyptians do not have health insurance coverage, whom are mainly residents of rural areas, employers in informal sectors, self-employed and farmers.Moreover, by looking at child mortality under age 5, despite that they are decreasing and reached to 24 children per 1000 live births in 2015 , the rate is still high comparing with the countries which have the lowest under5mortality rates in the world. Their under5- mortality rate is 3 children per 1000 live births. Thus, to sum up, some Egyptian are suffering from extravagance consumption in health expenditure despite that their health is weak. Turning to ne kind of ${ }_{i}$ haram products which is: Alcoholic Beverages, Tobacco and Narcotics as shown in table (1) in the Appendix that \%4.7 out of average per capita of family annual expenditure by major expenditure groups by tens categories of Egypt total in Year 2015 is spend on alcoholic 
beverage, tobacco and narcotics.Despite that Islam is specified as the state religion in Egypt and that principles of shariah is the primary source of legislation. Unfortunately, by looking at the percentage of Tobacco use in the following table:

Table (12): Tobacco use data from the latest survey results as at 31 December 2014

\begin{tabular}{|c|c|c|c|c|c|}
\hline & \multicolumn{2}{|c|}{ Youth Tobacco Use } & \multicolumn{2}{|c|}{$\begin{array}{c}\text { Adult Topacco } \\
\text { smoking }\end{array}$} & \multirow{2}{*}{\begin{tabular}{|c|}
$\begin{array}{c}\text { Adult cigarette } \\
\text { smoking }\end{array}$ \\
Daily
\end{tabular}} \\
\hline $\begin{array}{c}\text { Smoking } \\
\text { Prevalerice } \\
(\%)\end{array}$ & $\begin{array}{c}\text { Current } \\
\text { tobacco use } \\
\end{array}$ & $\begin{array}{l}\text { Current } \\
\text { Cigarette } \\
\text { smoking }\end{array}$ & Current & Daily & \\
\hline Male & 7.2 & 5.8 & 46.0 & 44.3 & 35.8 \\
\hline Female & 2.8 & 1.4 & 0.4 & 0.3 & - \\
\hline
\end{tabular}

Note that: Youth: ages 15-13, Adult: ages 64-25

Source: World Health Organization, "Egypt: WHO Report on the Globa! Tobacco Epidemic", 2015, page 2

As it is shown in the above table that Tobacco percentage of use relatively high despite the fact that Egypt is Muslim country and Islam is prohibiting smoking as smoking affects body causing health problems as cancer.Moreover, concerning alcoholic drinks, despite that tourism rate are fluctuating, alcohol sales are in an increase whereby companies as: Al-Ahram Beverages Co (ABC) and Egyptian International Beverages Co (EIBCO) are leading alcoholic drinks and launched numerous products in 2015. Thus, some Egyptians are consuming alcoholic expenditures despite that they are haram products and are making extravagance consumption of them. Thus, it can be concluded that the Egyptian society is a Consuming society, moreover, his consuming is far away from "Rational Element" whereby most Egyptians are suffering from extravagance spending.

And this explains the current Egyptian Economic situation, whereby:

Egypt's Balance of Payment (BOP) recorded deficit about $\$$ 3.7 billion dollars during the fiscal year 2016/2015. 
Egypt's Total external debt recorded $\$ 46.1$ billion dollars at the end of September 2015.

Therefore, despite being a Consuming society in Egypt, and that Egypt is borrowing to develop the Society and solve deficits, still Egypt is far away from achieving social welfare of the society. Thus, the solution ensuring "Rationality" principle in consumption.Thus, an arising question here is: How Islamic Rational consumption is going to solve the consumption spending problem?Rationality is something that is unique to the Islamic economic system.It is found out that consumer behavior has a certain focus in the Islamic system whereby, it provides certain rules in the market in addition it provides a set of rules for its economic agents. These rules are in the form of Shari'ah rules aiming at governing consumer behavior. The application of these rules may lead to the development of the institutions that are enabling individuals and also society to improve their well-being level on a path of sustainable development:Thus, by following the "Islamic Rationalism", consumption spending problem is going to be solved as:

- Islamic Rational consumption aims at making a right balance between: material needs and spiritual needs -on the contrary of the conventional thought of rationalism which focuses only on the material needs- where man could not neglect his share of the world and at the same time he seeks the abode of the hereafter.

- Since that, people living in the world as only temporary life and the hereafter life is the permanent one, as Islamic thought view, thus he aims at succeeding at the hereafter life, where by his success depends on the utilization of resources and best use of resources in the worldly life, so he aims at avoiding extravagance.

-Elimination of Israf and Tabthir should be main principles in solving consumption speriding problem. Whereby Tabthir is 
"spending your money on something which is not permissible to begin with, for example, drinking or the eating of pork". Israf is "spending on something which is otherwise permissible to spend your money on, but spending extravagantly". So Israf is extravagance.

- A man has to prevent Haram spending due to different harmful and not promising consequences resulting from this kind of spending as:

Haram spending lead to losing money.

Haram spending could lead to individual economic and social corruption, and this corruption may scatter to reach all layers of the society.

Haram spending results of losing the benefit of Halal utility, so there is no Halal utility.

Based on Islamic principles, resources will be allocated through Islamically valid means.

To sum up, "Islamiç "Rationàliśm" could solve "Consumption spending" problem through:

Focusing on shari'ah principles.

Encouraging Halal: spending and discouraging Haram spending.

Assures moderation in spending, so neither extravagant nor miser.

Promoting the welfare of the whole society through distributing a man's spending on both: material needs (his own self-interest) and spiritual needs (spending in the way of ALLAH).

Allocate resources efficiently and use Islamically valid means for the fulfillment of the mean

Encouraging Halal Utility. 


\section{Concluding remarks:}

1. The standard error is almost for the three methods of. regression but it has the smallest value in the LTS method.

2. The $R$ - squared measure has the largest value in the LTS method

3. The standard deviation is usually unknown which is estimated by the robust scale measure MAD when applying both the LTS and $M$ - estimation methods

4. The values of $A I C$ and $B I C$ measures for goodness of fit in urban sector are larger in urban sector than in rural sector

5. Measures of skewness and kurtosis have least values after removing the outliers than before removing them

6. When allocating the income to the experiditure groups in rural sector the group which contains the Food and NonAlcoholic Beverages has the largest share while in urban sector the group which contains education has the largest share

7. To calculate the Zakah, it is suggested to divide the individuals according to the median of their income or according to the code 1 or 0 into two groups in which the group of individuals which have income above this median or have code (0) are considered nonpoor and the group of individuals which have income under this median or have code (1) are considered poor

8. The most important conclusion is that, conventional economics should include normative and religious instrument to attain the goal of consumer satisfaction.

9. Zakah in Islam limits the excessive spending and the distribution of income to the expenditure groups leads to the planning of spending. 
71Dr. KHoloud Hossam - Dr. Nahed Helmy - Applying Islamic Rational Consumption

\section{Recommendation}

Actually, most individual's base decisions on social, pólitical and ethical considerations as well as on personal gain: Also, what people do may be strongly affected by habit, custom, and tradition. Every society weaves a fabric of institutions that guide its economic behavior.Zakah and charity are the only major sources of earning reward in the hereafter. The desire to increase income is strong for a Muslim consumer because hewould like to spend in the right way. Also, it is a Muslim's religious obligation to improve his economiç condition so that hebecomes a Zakah payer rather than a Zakah receiver. Islamic Rationalism" could solve "Consumption spending" problem through:

Focusing on shari'ah principles.

Encouraging Halal. spending and discouraging Haram spending.

Assures moderation in spending, so neither extravagant nor - miser.

Promoting the welfare of the whole society through distributing a man's spending"ọn both: material needs (his own self-interest) and spiritual needs (spending in the way of ALLAH).

Allocate resources êfficiently and use Islamically valid means for the fulfillment of the miean

\section{Encouraging Halal Ûțịtity.}

In rural sector it is, suggested to increase the share from income for both the edûcation and the health expenditure groups than the Food and Non-Álcoholic Beveragesgroup. In addition, it is suggested to increase the share from income for the health' expenditure group. 


\section{References}

Abaza, M. (2005). "Today's Consumption in Egypt", ISIM Review: Page 38

Abaza, M. (2006). "the Changing Consumer Cultures of modern . Egypt: Cairo's Urban Reshaping"

Abdin, A. and Gaafar, I. op.cit, Page 15

Abdin, A. and Gaafar, I. (2009). "Rational Water Use in Egypt", CIHEAM, Options Mediterraneennes, No.88, Page 4

Abu Talib, Maha (1999). "Rationalization of consumption and Challenges of Future", Dubai.

Adnan, A. A. (2011). "Isiamic Consumer Behavior (ICB): Its why and what", International Journal of Business and Social Science, Vol.2, No. 21

Agil, S.O.S. "Rationality in Economic Theory: A Critical Appraisal", Journal of Islamic Economics, Vol.2, No.2, page 87

Agil, S.O.S. Loc.cit

Agil, S.O.S. op.cit, page 89

Alderman, $H$. and von Braun, J. (1984). "The Effects of the Egyptian Food Ration and Subsidy system on Income Distribution and Consumption", International Food Policy Research Institute.

Al - Hadlaq, Norah (2010). "The Concept of Consumption in Globalization: a Critical Study in the Light of Islam", M. Sc Thesis, (Unpublished), Imam Muhammad Bin Saud Islamic University.

Central Bank of Egypt, "External Position of the Egyptian Economy", July/September 16/2015, No.51, page 1

Dawoud, S. (2005). "An Analysis of Food Consumption Patterns in. Egypt", Aus dem institut fur Ernahrungswirtchaft and Verbrauchslehre, Kiel, page 2 
Egyptian German Joint Committee on Renewable Energy. Energy Efficiency and Environmental Protection, "Impact of Energy Demand on Egypt's Oil and Natural, Gas Reserves: Current situation and perspectives to 2030", Federal Ministry for Economic Cooperation and Development, Cairo, June 2010, page 3

El-Ghonemy, M. R. (2003). "Egypt in the Twenty-First Century: Challenges for development", Routledge Curzon, page 51

El-Ghonemy, M. R. (2003). M. Riad El-Ghonemy, "Egypt in the Twenty-First Century: Challenges for development", Routledge Curzon, page 44:

El Gohary, R. op:cit, pp. 161-160

Elmenofi, G., Capone, R., Bottalico, F. and El Bilali, B. (2015). "An exploratory survey on household food waste in. Egypt", research gate, Page 1298

Elmenofi, G., Capone, R., Bottalico, F. and El Bilali, B. op.cit, page 1300

Elmenofi, G., Capone, R., Bottalico, F. and El Bilali, B. (2015). "An exploratory survey on household food waste in Egypt", research gate, Page 1298

Elmenofi, G., Capone, R., Bottalico, F. and El Bilali, B. op.cit, page 1300

Euromonitor International Website, http://www.euromonitor. com/alcoholic-drinks-in-gypt/report

FAO statistics Division 2010, "Food Balance Sheets", Food and Agriculture Organization of the United Nations, Rome, Authority Nutrition Website, https:/lauthoritynutrition com/how-manycalories-per-dayl 
Ghassan,H. B. (2015). "Islamic Consumer Model, Fairness Behavior and Asymptotic Utility", Munich Personal RePEc Archive (MPRA), page 9

Hassan B. G. (2015). "Islamic Consumer Model, Fairness Behavior and Asymptotic Utility", Munich Personal RePEc Archive (MPRA), page 2

Hassan, S. H., Marimuthu, M. and Cyril de Run, E. (2003). "Conceptualizing Convergence and Divergence of Muslim Consumption Behavior in Malaysia", Indian Journal of Management Scierice, Vol. III, page 43

Hasan, Z. (1985).." "Comment on: Macro Consumption Function in an Islamic Framework, written by: M. Fahim Khan", J. Res. Islamic Econ., Vol. 2, No.2, page 71

Hasan, Z. op.cit, page 72

Health : affairș $\because$ website, http://content heaithaffairs.orgl content/120/2/21 full.

Hinkley, D. V. (1975)."On Power Transformations to Symmetry", Biometrika, Vol. 62, pp. 111-101.

Hogg, R. .V. (1974). "Adaptive Robust Procedures: A Partial Review and Some Suggestions for Future Applications and Theory", Journal . of : the American 'Statistical Association, Vol: 69, pp. 927-909.

Hossain, B. (2014). "Economic Rationalism and Consumption: Islamic Perspective", Journal of Economics and Sustainable Development, Vol.5, No.24, page 115.

Hossain, B. (2014), Loc.cit

Hossain, B. op.cit, page 276 
Hossain, B. op.cit, page 273

Hossain, B. op.cit, page 275

Hossain, B. op.cit, page 116

Hossain, B. "Economic Rationalism and Consumption: Islamic Perspective", op. cit; pağe 277

Hsiao, C. "Pańel Datá Analysis-Advantageș and Challenges", page 4

Hsiao, C. (2003). "Analysis of Panel data", second edition, Cambridge University, pp 7-6

Ismail,S., Mousssa, A. and El Baz,B. (2015): "The oil and Gas Year: The Who's who of the Globe Energy Industry", page 15

Jafar, Eman (2006). “Transformations in the structure of Consumer Culture in Egyptian Society: Sociological Study of Changing Consumption Patterns in the Urban of Egypt by Application to a Selected Regional City (2000-1960)".

Kahf, M. (1991). "Lessons in Islamic Economics", Islamic Development Bank, Islamic Research and Training Institute (IRTI), Volume (1), Proceedings of the Seminar on "Teaching Islamic Economics University Level", page 266

Kamel, Heba (1990). "Theories of Total Consumption with Estimation of Consumption Function", Ain Shams University, Faculty of Commerce, department of Economics:

Khan, M. F. (1984). "Macro Consumption Function in an Islamic Framework", J. Res. Islamic Econ,, Vol. 1, No.1984, 2, page 4

Khan, M. F. (1984). Loc.cit

Khan, Z., Farooq, M. and Ullah, A. (2012). "Optimization of Consumption in Dịvine Context: (Basic Principleș and Extension)", Al-Idah, page 33

Khan, M. F. op.cit, page 8 
Khan, M. F. (2013): "An Alternative Approach to Analysis of Consumer Behavior: Need for a Distinctive "Islamic Theory", Journal of Islamic Business and Management, Vol.3, No.2, page 33

Kusuma, D. B. W., Muqorrobin, M., Krouchj, C. and Jamalauddin, N. (2013). "The Rational Behavior Concept in Islam and Policy Framework Perspectives", Research Gate, Global Review of Islamic Economics and Business, Vol.1, No.2, page 99.

Legatum Institute Website, http://www.prosperity.com/globel egypt.

"Legatum Prosperity Index": "Offers a unique insight into how prosperity is forming and changing across the world, it consists of 7 sub-indicators, which are: Economic Quality, Business Environment, Governance, Education, Health, Safety and Security, Personal Freedom, Social Capital and Natural Environment".

Medni, Nagah (2008). "Consumer Protection Mechanisms in the Islamic Economy", People's Democratic Republic of Algeria, Faculty of Social sciences and Islamic Sciences.

Ministry of Water Resources and Irrigation, "Water Scarcity in Egypt: The Urgent Need for Regional Cooperation among the Nile Basin Countries". February 2014, page 1

Multiple groups, "Health Care Sector Report 2015 ,2015, page 7

Nofal, R. M. (2006). "Family Economics and Rationalization of Consumption", Dar Al - Faysal International Publishing House Riyadh.

Okte; M. K.S. (2010). "Fundamentals of Islamic Economy and Finance: Theory and Practic: , Electronic Journal of Social Sciences, Vol.9, page 184

Quoquab, F., Abduallah, N. L. and Anmed, M. (2015). "Epicureanism and Global Consumerism in Shaping Muslim Buyers' Consumption Pattern: An Isla "nic Perspective", International Journal of Innovation and Business Strategy, Vol. 3, pp. 6 - 4 
77Dr. KHoloud Hossam - Dr. Nahed Helmy - Applying Islamic Rational Consumption

Rahim, Amal (2014). "A'ttitudes of the Saudi University Student Towards a Culture of Rationalization of Consumpition", a study applied in the Department of Social studies - Girls; King of Saud University.

Ramdan, R.(2015). "Demand and Supply Challenges of Food Security"; The Egyptian: Center for Economic Studies, Review No.2, page 4

Ramdan, R. op.cit, påge 7

Rohani, S: S. A. : "Is religiosity an important determinant on. Muslim consumer' behấvior in Malaysia", Journal of Islamic Marketing, Vol.2, page 85.

The Ministry of "finance websitehttp:/www.budget.gov. eg/Budget20142015/Budget/2ca0bea0-2bc453-8f-adb-7 cb1de74ce781

Trading Economics' website, http://www.tradingeconomics. com/egypt/imports .

United States Department of State, "Egypt 2013: International religious Freedom, Report", 2013, page 2

Wani, T. A. "Buỵng" Behavior-An Islamic Perspective", The Journal of commerce, Vol.5, No.2, page 6

Wilcox, R. (2012). Introduction to Robust Estimation and Hypothesis Testing. USA, Elsevier Inc.

World Bank Website, http://data.albankaldawli.org/indicator/ NE.CON.PETC.ZS?locations=EG,

World Health. Organization Website, http://www.who.int/ countries/egy/en/

Zia, M.D. and Nasir-Ud-Din, N. (2016). "Islamic Economic Rationalism and Distribution of Wealth: A Comparative View", IOSR Journal of Business and Management (IOSR-JBM), Vol. 18 , Issue 4 , page 43.

Zia, M.D. and Nasir-Ud-Din, N. (2016). Loc.cit. 


\section{Appendix}

The used Model is "A multiple linear regression model", it is a very advanced statistical and it is extremely powerful when you are trying to develop a "model" for predicting a wide variety of outcomes. A multiple linear regression model is a linear model that describes how a " $Y$ " variable relates to two or more " $X$ " variables., where the equation of the multiple regression is:

$$
Y=a+b_{1} x+b_{2} x_{2}
$$

The model will be estimated using (SAS and R) programs and will be presented as following:

$$
C_{i t}^{*}=a+b_{1} Y_{i 1}+b_{2} P \cdot R_{i t}+b_{3} G_{i 1}+b_{4} A G+{ }_{4} e_{i l} \text {. }
$$

where:

$C^{*}:$ is the dependent variable

Y,PR, G, AG: are the dependent variables.

$\mathrm{a}$ : is the constant (Intercept)

$b_{1}, b_{2}, b_{3}, b_{4}$ : are the slope of the independent variables on $C^{*}$ respectively.

$t$ is referring to time periods

i: is the number of levels

$\mathrm{e}:$ is the error

The explanation of the variables that will be used in the model:

\section{C*: Islamic Rational Consumption:}

It is the consumption after dedıcting the Haram consumption and adding the independent variables that form the Islamic Rational Consumption.

\section{Y: Islamic Rational Household Income Variable:}

Household income is one of the main independent variables and is a main determinant of household consumption. By looking 
79Di. KHoloud Hossam - Dr. Nahed Helmy -Applying Islamic Rational Consumption

at the Distribution of Households by Groups of Annual Household Income, it is found out that the society is divided into 20 income levels (according to the CAPMAS) ranging from less than 10,000 Egyptian pounds per year for Individual to more than 100,000 . Egyptian pounds per year for each individual.

Since that the main is to measure Islamic Rational Consumption therefore the Islamic Rational Income should be measured.

Thus, Islamic rational Household Income will be measured by inclüding family annual expenditure by major expenditure groups according to Islamic rationality

where:

$Y_{\mathrm{it}}=r_{1} F_{i t}+r_{2} S_{i t}+r_{3} H_{i t}+r_{4} T_{i t}+r_{5} L_{i t}+r_{6} E_{H t}+r_{7} P_{h t}+r_{8} R_{i t}+r_{9} M_{i t}+r_{10} I$ it $+r_{11}^{\prime} V_{i t}+e_{i t}$

where:

- Table (1): Variables that will be included in the previous

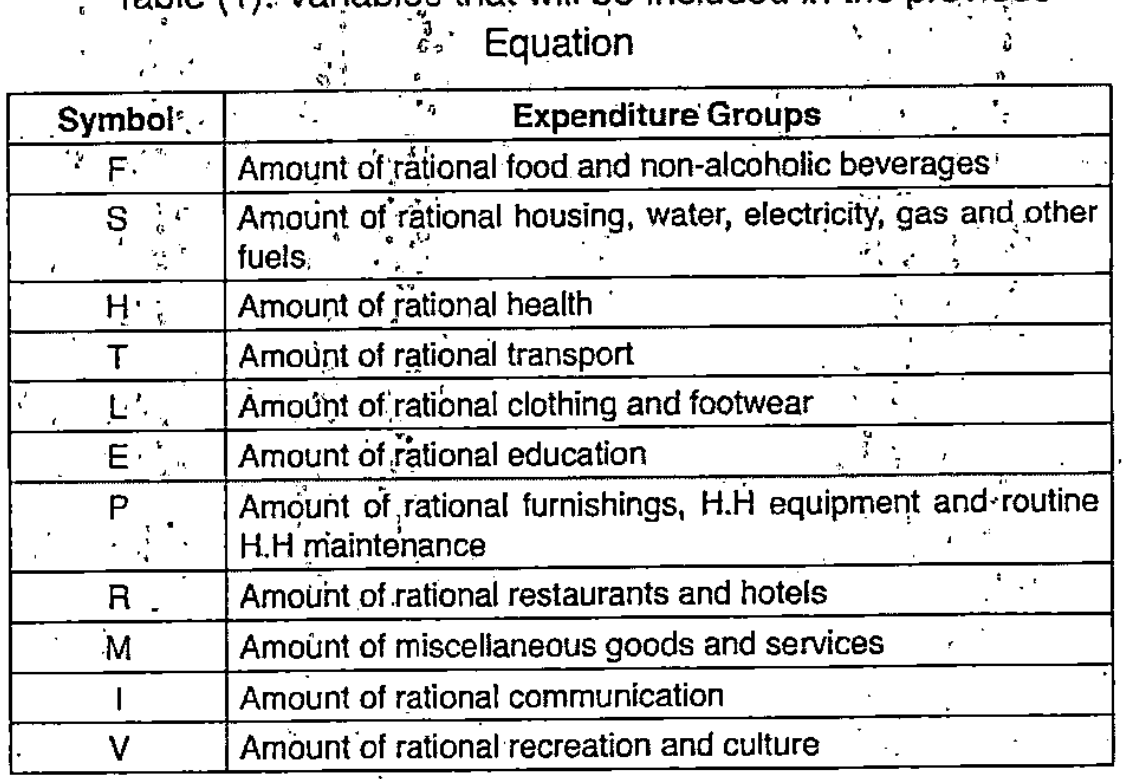

Note that: Consumption of Alcoholic beverages, Tobacco and other Haram products are eliminated from the equation since that the study is concerned only with Halal products that are in accordance with shariah. 


\section{PR: Place of Residence Variable:}

It is one of the main determinants of that have an impact on household consumption expenditure, whereby the pattern of spending on different expenditure varies according to urban and rural areas.

\section{G: Gender Variable:}

It is one of the determinants that have an impact on household consumption expenditure, whereby the pattern of spending differs according to the gender as Male or Female.

\section{AG:Age Variable:}

It is one of the determinants that have an impact on household consumption expenditure, whereby the pattern of spending differs according to the age

The outputs of applying the ordinary least squares on the data of the urban sector using $R$ program are shown in Table (2).

Table (2): the outputs of the ordinary least squares on the data of the urban sector

\begin{tabular}{|c|c|c|c|c|}
\hline & Estimate & Std. Error & T value & $P$ - value \\
\hline Intercept & 4204 & 3442 & 1.222 & 0.22235 \\
\hline & -27.91 & 21.87 & -1.276 & 0.20244 \\
\hline & 2245 & 448.2 & 5.01 & $7.19 \mathrm{e}-7$ \\
\hline & 1518 & 547.8 & 2.771 & 0.00577 \\
\hline & 0.3725 & 0.005825 & 63.591 & $2 e-16$ \\
\hline
\end{tabular}

"These calculations are by the researcher

The regression equation from applying the OLS method is given by:

Where the negative value rf lects the reverse relation between the dependent variable (total expenditure) and the independent variable (the economic sector). The positive value 2245 reflects the positive relationship between the and the independent 
81Dr. KHoloud Hossam - Dr. Nahed Helmy - Applying Islamic Rational Consumption

variable (the education status). The positive value 1518 reflects the positive relationship between the and the independent variable (the family size). The positive value 0.3725 reflects the positive relationship between the and the independent variable (the income).Residual standard error for these data is 21670 . Multiple R - squared is 0.8805 means that $\% 88.05$ from the total variation of the dependent variable is explained by the regression line and the independent variables. Adjusted $R$ - squared is 0.8797 . The summary statistics for the data of the urban sector is given in table (3).

Table (3): the summary statistics of the data from the urban sector

\begin{tabular}{|c|c|c|c|c|}
\hline Min & $1 Q$ & Median & $3 Q$ & Max \\
\hline-92382 & -7490 & -1783 & 3913 & 366225 \\
\hline
\end{tabular}

*These calculations are by the researcher

The outputs of applying the LTS method before removing the outliers in the data of the urban sector using SAS program are shown in table (4).

Table (4): the estimates for the variables under study

\begin{tabular}{|c|c|}
\hline & Estimate \\
\hline Parameter & -99.4647 \\
\hline Intercept & 1.3508 \\
\hline 3 & 615.5205 \\
\hline & 775.1413 \\
\hline Scale (sLTS) & 0.7019 \\
\hline
\end{tabular}

"These calculations are by the researcher

The regression equation from applying the LTS method before removing the outliers from the data is given by:

Where the positive value reflects the positive relationship between the dependent variable (total expenditure) and the independent variable (the economic sector). The positive 
value reflects the positive relationship between the and the independent variable (the education status). The positive value reflects the positive relationship between the and the independent variable (the family size). The positive value reflects the positive relationship between the and the independent variable (the income).Diagnostics summary for the data of the urban sector is given in table (5).

Table (5): diagnostics summary for urban data

\begin{tabular}{|c|c|}
\hline Observation Type & Proportion \\
\hline . Outlier & 0.08 \\
\hline R - square & 0.8258 \\
\hline
\end{tabular}

"These calculations are by the researcher

It is noticed that the proportion of outliers in the data is $\% 8$. $R$ - squared for LTS estimation is 0.8258 means that \%82.58 from the total variation of the dependent variable is explained by the regression line and the independent variables.Parameter estimates for final weighted least squares after removing the outliers from the data are given in table (6) for the urban data.

Table (6): Parameter estimates for final weighted least squares fit for urban sector

\begin{tabular}{|c|c|c|c|c|c|c|c|}
\hline \multicolumn{7}{|c|}{ Parameter Estimates for Final Weighted Least Squares Fit } \\
\hline $\begin{array}{c}\text { Paramet } \\
\text { ef }\end{array}$ & df & Estimates & $\begin{array}{c}\text { Standard } \\
\text { error }\end{array}$ & \multicolumn{2}{|c|}{$\begin{array}{c}95 \% \text { Confidence } \\
\text { interval limits }\end{array}$} & $\begin{array}{c}\text { Chi }- \\
\text { Square }\end{array}$ & P - value \\
\hline Intercept & 1 & -445.943 & 1022.018 & -2449.06 & 1557.175 & 0.19 & 0.6626 \\
\hline $\mathrm{X} 1$ & 1 & 1.0948 & 6.4538 & -11.5545 & 13.7441 & 0.03 & 0.8653 \\
\hline $\mathrm{X} 2$ & 1 & 459.2981 & 144.5956 & 175.896 & 742.7003 & 10.09 & 0.0015 \\
\hline $\mathrm{X} 3$ & 1 & 1075.179 & 165.5849 & 750.6383 & 1399.719 & 42.16 & 0.0001 \\
\hline $\mathrm{X} 4$ & 1 & 0.6905 & 0.0146 & 0.6619 & 0.7191 & 2244.14 & 0.0001 \\
\hline Scale & 0. & 6121.671 & & & & & \\
\hline
\end{tabular}

*These calculations are by the researcher 
830r. KHoloud Hossam - Dr. Nahed Helmy - Applying Islamic Rational Consumption

The regression equation from applying the Final Weighted Least Squares after removing the outliers from the data is given by:

Where the positive value reflects the positive relationship between the dependent variable (total expenditure) and the independent variable (the economic sector). The positive value reflects the positive relationship between the and the independent variable (the education status). The positive value reflects the positive relationship between the and the independent variable (the family size). The positive value reflects the positive relationship between the and the independent variable (the income).Summary statistics for the dependent and the independent variables from applying LTS method in urban sector are given in table (7).

Table (7): summary statistics for urban sector

\begin{tabular}{|c|c|c|c|c|c|c|}
\hline $\begin{array}{c}\text { Variable } \\
.\end{array}$ & Q1 & Median & Q3 & Mean & $\begin{array}{c}\text { Standard } \\
\text { Deviation }\end{array}$ & MAD \\
\hline$X 1$ & 3 & 4 & 100 & 34.6517 & 44.9215 & 4.4478 \\
\hline$X 2$ & 3 & 6 & 6 & 5 & 2.0842 & 2.9652 \\
\hline$X 3$ & 3 & 4 & 5 & 3.9583 & 1.7612 & 1.4826 \\
\hline$X 4$ & 26801.8 & 39266.6 & 55853 & 53631.5 & 153938 & 20503.9 \\
\hline$Y$ & 22933.1 & 32167.8 & 45151.3 & 40450.1 & 62466.2 & 15713.4 \\
\hline
\end{tabular}

'These calculations are by the researcher

Parameter estimates from applying the $M$ - estimation on the - data of the urban sector using SAS program are shown in table (8) 
. Table (8): parameter estimates for urban sector

\begin{tabular}{|c|c|c|c|c|c|c|c|}
\hline \multicolumn{7}{|c|}{ Parameter Estimates } \\
\hline \begin{tabular}{c}
\hline Paramete \\
$\mathrm{r}$
\end{tabular} & $\mathrm{df}$ & Estimates & $\begin{array}{c}\text { Standard } \\
\text { error }\end{array}$ & \multicolumn{2}{|c|}{$\begin{array}{c}\text { 95\% Confidence } \\
\text { interval limits }\end{array}$} & $\begin{array}{c}\text { Chi - } \\
\text { Square }\end{array}$ & $P$ - value \\
\hline Intercept & 1 & -313.393 & 1058.008 & -2387.05 & 1760.264 & 0.09 & 0.7671 \\
\hline $\mathrm{X} 1$ & 1 & -0.2589 & 6.7243 & -13.4383 & 12.9204 & 0 & 0.9693 \\
\hline $\mathrm{X} 2$ & 1 & 448.1174 & 137.7808 & -178.0722 & 718.1629 & .10 .58 & 0.0011 \\
\hline $\mathrm{X} 3$ & 1 & 1037.351 & 168.3943 & 707.304 & 1367.398 & 37.95 & 0.0001 \\
\hline $\mathrm{X} 4$ & 1 & 0.6974 & 0.0018 & 0.6939 & 0.7009 & 151684 & 0.0001 \\
\hline Scale & 1 & 5613.223 & & & & & \\
\hline
\end{tabular}

*These calculations are by the researcher

The regression equation from applying the LTS is given by:

Where the negative value reflects the reverse relation between the dependent variable (total expenditure) and the independent variable (the economic sector). The positive value reflects the positive relationship between the and the independent variable (the education status). The positive value reflects the positive relationship between the and the independent variable (the family size). The positive value reflects the positive relationship between the and the independent variable (the income). The robust estimate for the scale parameter is 5613.223. Diagnostics summary for the data of the urban sector are given in table (9).

Table (9): diagnostics summary for urban data

\begin{tabular}{|c|c|}
\hline Observation Type & Proportion \\
\hline Outlier & 0.0867 \\
\hline
\end{tabular}

- These calculations are by the researcher 
85Dr. KHoloud Hossam - Dr. Nahed Helmy - Applying Islamic Rational Consumption

$\therefore$ It is noticed that the proportion of outliers in the data is $\% 8.67$. Goodness - of - fit measures for the urban data is given in table (10). Table (10): Goodness - of - fit measures for the urban data

\begin{tabular}{|c|c|}
\hline \multicolumn{2}{|c|}{ Goodness - of - Fit } \\
\hline$\because \quad$ Statistic & Value \\
\hline R-Square & 0.578 \\
\hline AICR & 901.2104 \\
\hline BICR & 924.2982 \\
\hline
\end{tabular}

These calculations are by the researcher

$R$ - squared for LTS estimation is 0.578 means that $57.8 \%$ from the total variation of the dependent variable is explained by the regression line and the independent variables. The outputs of applying the OLS method on the data of the rural sector using $R$ program are shown in table (11).

Table (11): the outputs of OLS method on the data of the rural sector

\begin{tabular}{|c|c|c|c|c|}
\hline & Estimate & Std. Error & Tvalue & P-value \\
\hline Intercept & 7426.68178 & 2633.38163 & 2.86 & 0.00496 \\
\hline$X 1$ & 6.12692 & 18.23961 & -0.336 & 0.73705 \\
\hline$X 2$ & 720.58187 & 366.22929 & 1.968 & 0.04958 \\
\hline$X 3$ & -188.97786 & 401.15613 & -0.471 & 0.63775 \\
\hline$X 4$ & 0.95801 & 0.05211 & 18.383 & $2 \mathrm{e}-16$ \\
\hline
\end{tabular}

*These calculations are by the researcher

The regression equation from applying the OLS method is given by:

Where the negative value refiects the reverse relation between the dependent variable (total expenditure)-and the independent variable. (the economic sector). The positive value reflects the 
positive relationship between the and the independent variable (the education status). The positive value reflects the positive relationship between the and the independent variable (the family size). The positive value reflects the positive relationship between the and the independent variable (the income). Residual standard error for these data is 16720 . Multiple $R$ - squared is 0.421 means that $\% 42.1$ from the total variation of the dependent variable is explained by the regression line. Adjusted $R$-squared is $\% 41.71$. The summary statistics for the data of the rural sector is given in table (12).

Table (12): the summary statistics of the data from the rural sector

\begin{tabular}{|c|c|c|c|c|}
\hline Min & $1 Q$ & Median & $3 \mathrm{Q}$ & Max \\
\hline-143634 & -6616 & -2846 & 3080 & 244028 \\
\hline
\end{tabular}

*These calculations are by the researcher

The parameter estimates from applying the LTS method on the data of the rural sector using SAS program are shown in table (13).

Table (13): the parameter estimates for the variables under study

\begin{tabular}{|c|c|}
\hline Parameter & Estimate \\
\hline Intercept & 4020.77 \\
\hline & \\
\hline 3 & 3.8011 \\
\hline Scale (sLTS) & 1.0197 \\
\hline
\end{tabular}

"These calculations are by the researcher

The regression equation from applying the LTS before removing the outliers from the data is given by: 
87Dr. KHoloud Hossam - Dr. Nahed Helmy - Applying Islamic Rational Consumption

Where the negative value reflects the reverse relation.between the dependent variable (total expenditure) and the independent variable (the economic sector). The negative value reflects the reverse relation between the and the independent variable $\therefore$ (the education status). The positive value reflects the positive relationship between the and the independent variable (the family size). The positive value reflects the positive relationship between the and the independent variable (the income). The robust estimate for the scale parameter is 6322.527.Diagnostics summary for the data of the rural sector is given in table (14).

Table (14): diagnostics summary for rural data

\begin{tabular}{|c|c|}
\hline Observation Type & Proportion \\
\hline Outlier & 0.0967 \\
\hline R-square & 0.7815 \\
\hline
\end{tabular}

"These calculations are by the researcher

It is noticed that the proportion of outliers is $\% 96.7$ in the data under study. R - squared for LTS estimation is 0.7815 means that $\% 78.15$ from the total variation in the dependent variable is explained by the regression line and the independent variables. Parameter estimates for final weighted least squares after removing the outliers from the data are given in table (15) for the urban data. 
Table (15): Parameter estimates for final weighted least squares fit for rural sector

\begin{tabular}{|c|c|c|c|c|c|c|c|}
\hline \multicolumn{7}{|c|}{ Parameter Estimates for Final Weighted Least Squares fit } \\
\hline $\begin{array}{c}\text { Parameter } \\
\text { Intercept }\end{array}$ & 1 & 5274.282 & 1080.071 & 3157.382 & 7391.182 & 23.85 & 0.0001 \\
\hline $\mathrm{X} 1$ & 1 & -4.012 & 7.212 & -18.1472 & 10.1232 & 0.31 & 0.578 \\
\hline $\mathrm{X} 2$ & 1 & 21.826 & 146.9306 & -265.153 & 309.8047 & 0.02 & 0.8819 \\
\hline $\mathrm{X3}$ & 1 & 160.5037 & 165.2148 & -163.311 & 484.3189 & 0.94 & 0.3313 \\
\hline $\mathrm{X} 4$ & 1 & 0.9907 & 0.0266 & 0.9386 & 1.0429 & 1388.63 & 0.0001 \\
\hline Scale & 0 & 6283.38 & & & & & \\
\hline
\end{tabular}

-These calculations are by the researcher

The regression equation from applying the Final Weighted Least Squares after removing the outliers from the data is given by:

Where the negative value reflects the reverse relation between the dependent variable (total expenditure) and the independent variable (the economic sector). The negative value reflects the positive relationship between the and the independent variable (the education status). The positive value reflects the positive relationship between the and the independent variable (the family size). The positjve value reflects the positive relationship between the and the independent variable (the income). The robust estimate for the scale parameter is 6283.38.Summary statistics for the dependent and the independent variables from applying LTS method in the rural sector are given in table (16). 
89Dr. KHolouid Hossam - Dr. Nahed Helmy - Applying Islamic Rational Consumption

Table (16): summary statistics for rural sector when applying

LTS method

\begin{tabular}{|c|c|c|c|c|c|c|}
\hline $\begin{array}{c}\text { Variable } \\
\because \\
\because\end{array}$ & Q1 & Median & Q3 & Mean & $\begin{array}{l}\text { Standard } \\
\text { Deviation }\end{array}$ & MAD \\
\hline$\cdot \times 1$ & 4 & 9 & 9 & 28.3383 & 40.5945 & 7.413 \\
\hline$\times 2$ & 2 & 5 & $\overline{6}$ & 4.25 & 2.0152 & 2.9652 \\
\hline$\therefore \quad \times 3$ & 3 & 5 & 6 & 4.5217 & 1.8838 & 1.4826 \\
\hline$\because \times 4$ & 20765.8 & 27443.3 & 35866.4 & 29875.9 & 14454.2 & 10585.4 \\
\hline$\because Y Y$ & 25093 & 33693.9 & 45050.7 & 38082.5 & 21895.6 & 13939.4 \\
\hline
\end{tabular}

These calculations are by the researcher

Parameter estimates from applying the $M$ - estimation on the data of the rural sector using SAS program are shown in table (17).

Table (17): parameter estimates for rural sector

\begin{tabular}{|c|c|c|c|c|c|c|c|}
\hline \multicolumn{7}{|c|}{ Parameter Estimates } \\
\hline Parameter & df & Estimates & $\begin{array}{c}\text { Standard } \\
\text { error }\end{array}$ & $\begin{array}{c}95 \% \text { Confidence } \\
\text { interval limits }\end{array}$ & $\begin{array}{c}\text { Chi- } \\
\text { Square }\end{array}$ & $\begin{array}{c}\text { P-value } \\
\because\end{array}$ \\
\hline \hline Intercept & 1 & 4049.187 & 1104.325 & 1884.749 & 6213.624 & 13.44 & 0.0002 \\
\hline$X 1$ & 1 & -3.9058 & 7.6489 & -18.8973 & 11.0858 & 0.26 & 0.6096 \\
\hline$X 2$ & 1 & 156.0477 & 153.5805 & -144.965 & 457.06 & 1.03 & 0.3096 \\
\hline$X 3$ & 1 & 102.2988 & 168.2273 & -227.421 & 432.0183 & 0.37 & 0.5431 \\
\hline$X 4$ & 1 & 1.0234 & 0.0219 & 0.9806 & 1.0663 & 2193.07 & 0.0001 \\
\hline Scale & 1 & 6373.812 & & & & & \\
\hline
\end{tabular}

*These calculations are by the researcher 
The regression equation from applying the $M$ estimation method is given by:

Where the negative value reflects the reverse relation between the dependent variable (total expenditure) and the independent variable (the economic sector): The negative value reflects the positive relationship between the and the independent variable (the education status). The positive value 102.2988reflects the positive relationship between the and the independent variable (the family size). The positive value 1.0234 reflects the positive relationship between the : and the independent variable (the income). The robust estimate for the scale parameter is. 6373.812 . Diagnostics summary for the data of the rural sector is given in table (18).

Table (18): diagnostics summary for urban data

\begin{tabular}{|c|c|}
\hline Observation Type & Proportion \\
\hline Outlier & 0.0933 \\
\hline
\end{tabular}

*These calculations are by the researcher

It is noticed that the proportion of outliers is $\% 9.33$ in the data under study.Goodness - of - fit measures for the rural data is given in table (19).

Table (19): Goodness - of - fit measures for the rural data

\begin{tabular}{|c|c|}
\hline \multicolumn{2}{|c|}{ Goodness - of - Fit } \\
\hline Statistic & Value \\
\hline R-Square & 0.5045 \\
\hline AICR & 860.4061 \\
\hline BICR & 884.5158 \\
\hline
\end{tabular}

*These calculations are by the researcher

$\mathrm{R}$ - squared for $\mathrm{M}$ - estimation is 0.5045 means that $\% 50.45$ from the total variation in the dependent variable is explained by the regression line and the independent variables. 
91 Dir. KHoloud Hossam - Dr. Nahed Helmy - Applying Islamic Rational Consumption

\section{تمبليق الاسترالك الرشيل من منظور إبلاميي.}

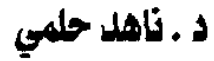 \\ الستاذ الاحصاء|المسناعلد
}

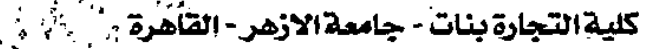

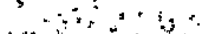

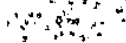

$\therefore$

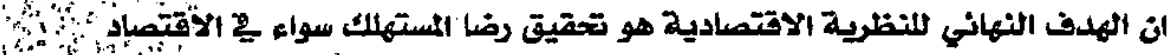

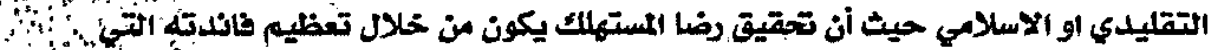

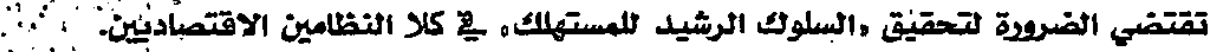

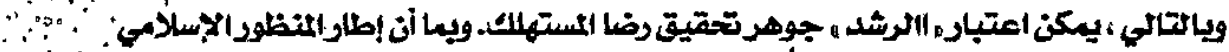

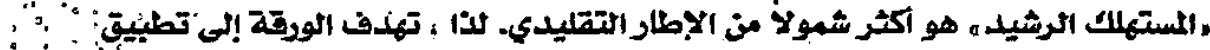

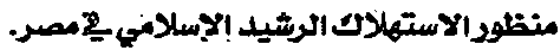

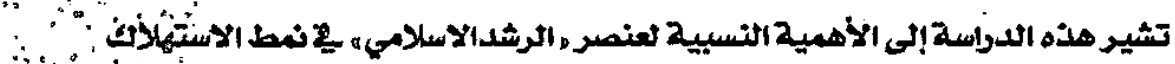

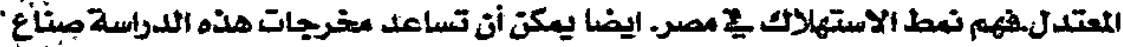

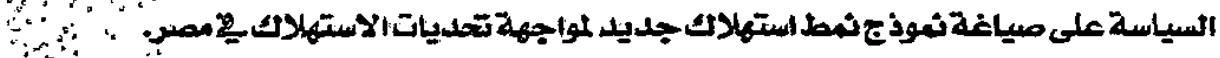

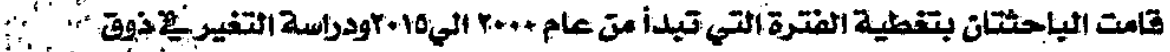

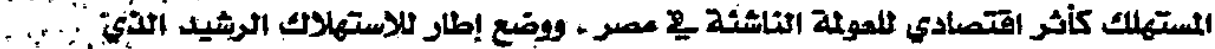

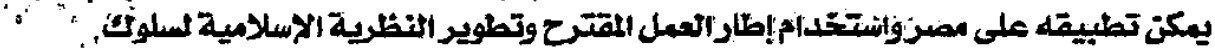

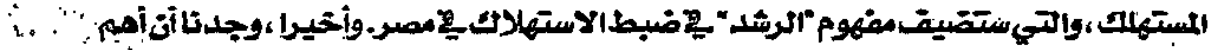

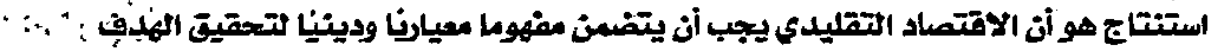

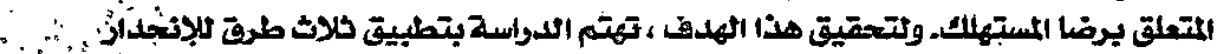

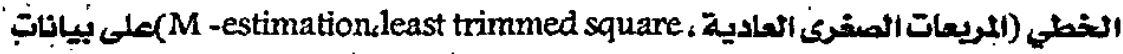

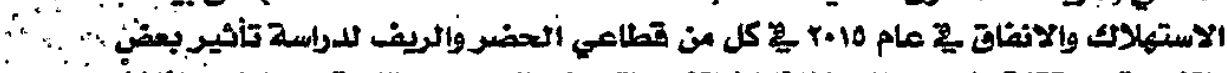

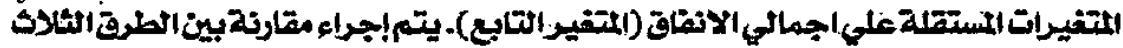

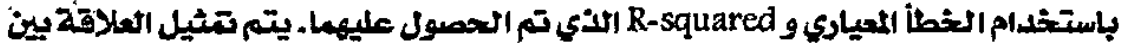

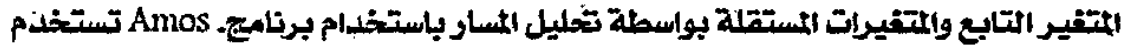

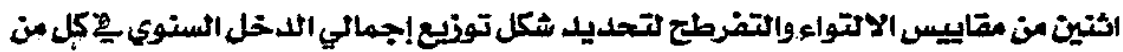

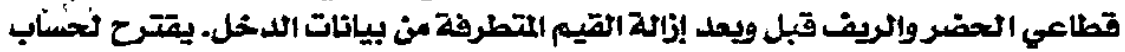

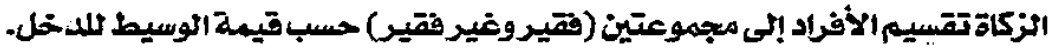

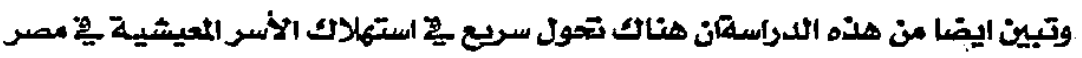

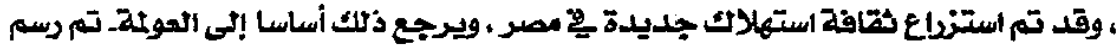

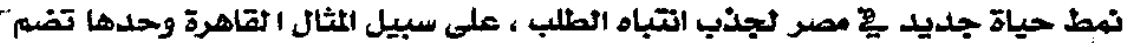

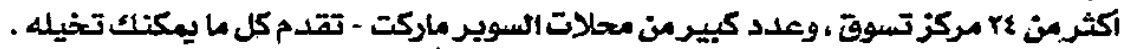




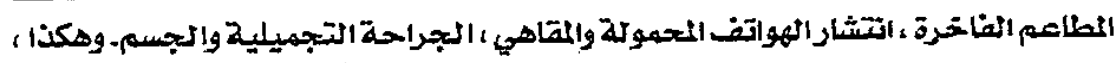

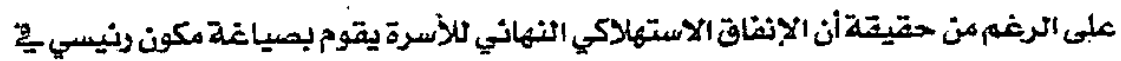

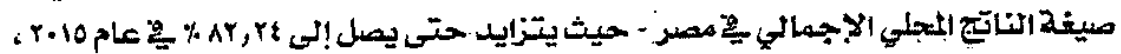

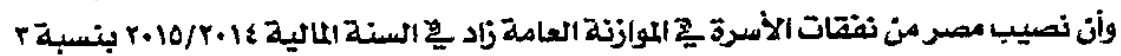

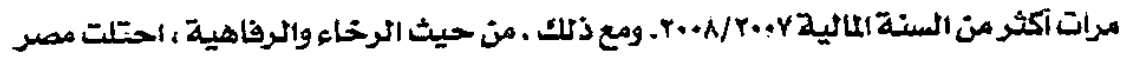

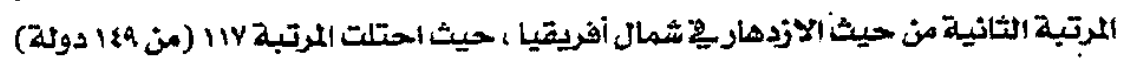

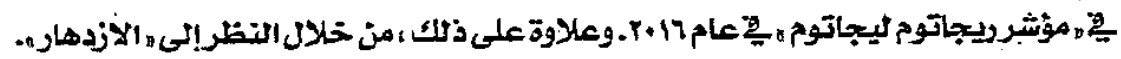

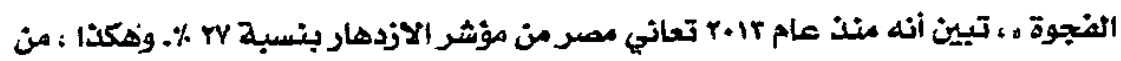

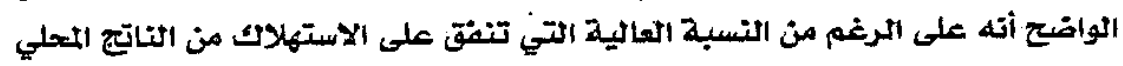

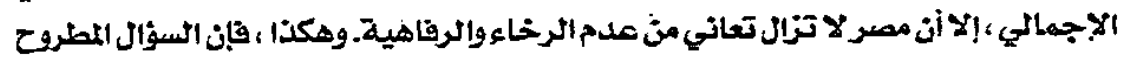

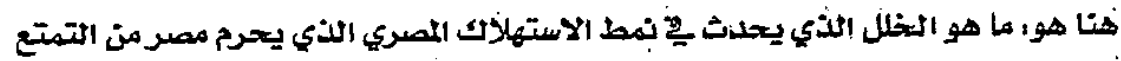

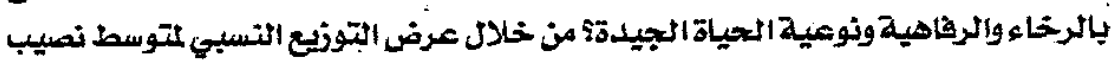

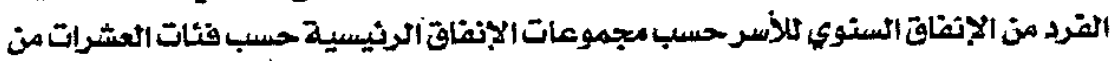

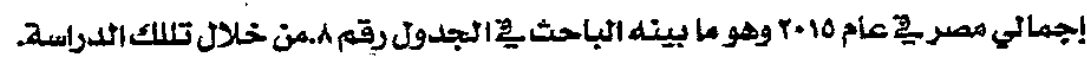

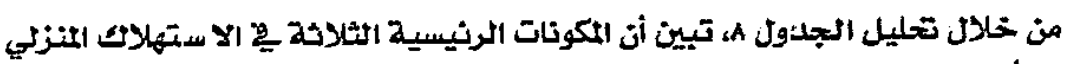

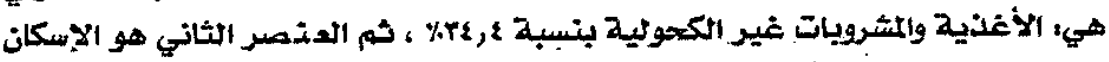

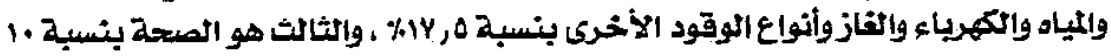

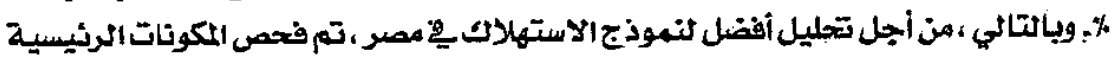

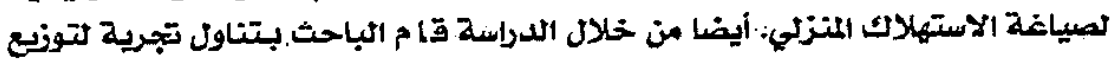

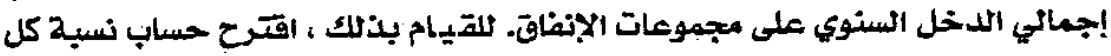

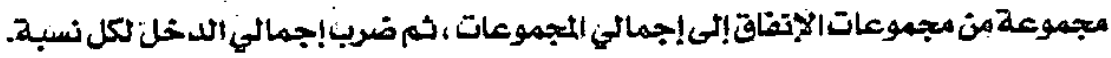

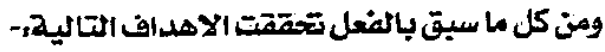

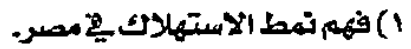

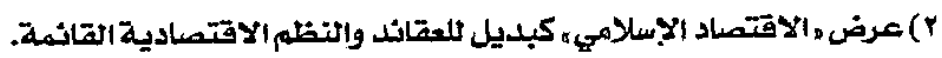

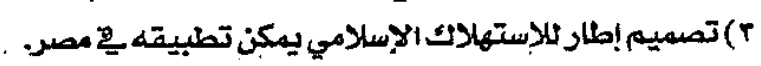

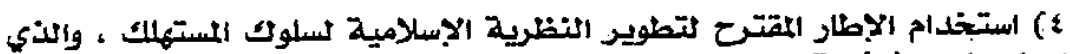

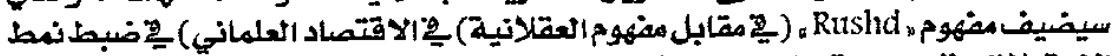

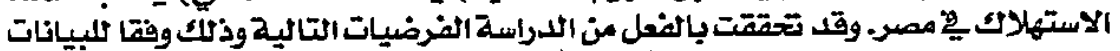

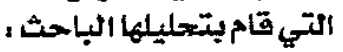

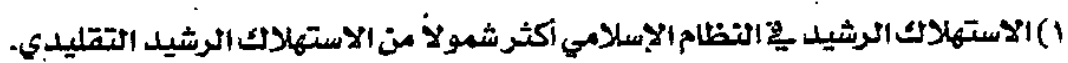
r) مصر تعاني مت ألاتفاق وإلبدخ.

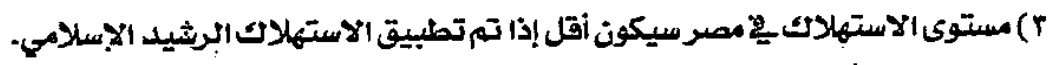

